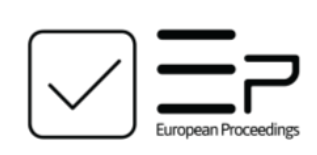

European Proceedings of

International Conference on Education \&

Educational Psychology

EPICEEPSY

www.europeanproceedings.com

e-ISSN: 2672-8141

DOI: $10.15405 /$ epiceepsy.21101.1

ICEEPSY 2021

$12^{\text {th }}$ International Conference on Education \& Educational Psychology

\title{
VALIDATED INTERPERSONAL CONFIDENCE QUESTIONNAIRE TO MEASURE THE IMPACT OF IMPROVISATION TRAINING
}

\author{
Sirke Seppänen (a)***, Johanna Novák (b) ${ }^{* *}$, Tapio Toivanen (a), Kaisa Tiippana (c) \\ *Corresponding author; ${ }^{* *}$ Shared first authorship
}

(a) Faculty of Educational Sciences, University of Helsinki, PO Box 8, FI-00014 University of Helsinki, Finland. sirke.seppanen@helsinki.fi

(b) Faculty of Education, University of Turku, FI-20014 University of Turku, Finland

(c) Department of Psychology and Logopedics, Faculty of Medicine, University of Helsinki, PO Box 9, FI-00014

University of Helsinki, Finland

\begin{abstract}
Theatre-based improvisation includes a model of constructive communication, which has been applied to education, and in fields requiring interpersonal competencies. Here, we present a validation study of the Interpersonal Confidence Questionnaire (ICQ) developed to measure self-reported interpersonal confidence, that is, beliefs regarding one's capability related to effective social interactions. Confirmatory factor analysis $(n=208)$ confirmed the 18-item measurement model of ICQ as satisfactory, with six factors contributing to interpersonal confidence: performance confidence, flexibility, listening skills, tolerance of failure, collaboration motivation, and presence. The questionnaire showed discriminatory power, acceptable composite reliability, and strong test-retest reliability. The immediate and long-term impact of six improvisation interventions $(\mathrm{n}=161)$ were measured using ICQ. Improvisation interventions resulted in improvements to interpersonal confidence, performance confidence, and tolerance of failure relative to controls, and an improved performance confidence persisted over time. This study provides initial evidence on the validity and reliability of the 18-item, 6-factor ICQ as a self-report measurement of interpersonal confidence, which may increase following improvisation training.
\end{abstract}

2672-8141 @ 2021 Published by European Publisher.

Keywords: Improvisation, interpersonal confidence, performance confidence, tolerance of failure, questionnaire validation 


\section{Introduction}

A theatre-based improvisation method ${ }^{1}$ lends itself to move from an on-stage performance to serving as a tool to pursue nondramatic purposes. As an art form, improvised games or plays are created spontaneously on stage without a manuscript, commonly spiced by suggestions from the audience. At the other end of the improvisation continuum, we find an applied form of theatre art with specific goals, such as enhancing communication or creativity at work (Aadland et al., 2017; Pereira Christopoulos et al., 2016; Sawyer, 2004, 2006). Whether a genre of performance theatre or an instrument applied to various contexts, improvisational activity requires participants collaborate with one another rather than focus on their own ideas, goals, or egos (Lobman, 2005).

By definition, the core characteristic of improvisation is the lack of preparation (the Latin root of the word improvisation 'improviso', means 'unforeseen; not studied or prepared beforehand'). Given this lack of preparation, improvisers must resort to each other's instant ideas and environmental cues to proceed through a scene together. Thus, the core component of improvisation is mutual and unconditional support towards any idea the co-improviser presents. This generates psychological safety, since there is no need to fear mistakes nor failure resulting in the loss of social status or social rejection (Gerber, 2009; Vera \& Crossan, 2005). Mistakes are not evaluated as errors, but merely as unexpected events directing the scene differently than anticipated (Barrett, 1998; Vera \& Crossan, 2005). Thus, improvisation trains individuals to abandon anticipating forthcoming events and to resist the temptation to plan what should happen next. In other words, improvisation encourages individuals to focus on the present and to act together in a flexible manner. Combined with mutual support, the elements of connection and collaboration are at the forefront in improvisational mindset.

Viola Spolin and Keith Johnstone in particular developed methods to develop this mindset. Spolin (1999) created her training method in the $1950 \mathrm{~s}$ in an attempt to encourage immigrant youth to integrate into American society. In the 1960s, Johnstone $(1985,1999)$ pursued sparking spontaneity and creativity among actors by coaching them to abandon their need to be funny or clever and to accept any idea without evaluating it as good or bad (Drinko, 2013a). In subsequent decades, these intertwined methods have evolved to represent the global improvisation scene of today. The current field of improvisation embraces a large variety of on-stage forms, from theatre sports competitions to full-length plays as well as applied forms that utilise the improvisational skill set as a tool to benefit personal growth, education, or business (Aadland et al., 2017; Benjamin \& Kline, 2019; Kirsten \& du Preez, 2010; Schwenke et al., 2020; Vera \& Crossan, 2004).

The focus on interdependence and adaptability might explain why improvisation has been applied to fields where collaboration is vital, and which require a tolerance for uncertainty. For example, in the field of education, improvisation has been recommended as a tool to develop teachers' interaction skills (Graue et al., 2015; Lehtonen et al., 2016; Lobman, 2006; Sawyer, 2004, 2006; Toivanen et al., 2011) and creativity when teaching (Aadland et al., 2017; Lobman, 2005, 2014; Sawyer, 2012). Drinko (2013b) and Lobman (2006) argue that improvisation enhances listening skills and situation-focused sensitivity, leading

\footnotetext{
${ }^{1}$ We refer to a method originating from the medieval Commedia dell' arte, developed further by, for instance, Konstantin Stanislavski in Europe, Viola Spolin (1999) in the United States and Keith Johnstone (1985) in United Kingdom and Canada.
} 
to a heightened perception of subtle verbal and nonverbal cues from pupils and, ultimately, to better ensemble collaboration. Furthermore, medical education (Gao et al., 2018; Hoffmann-Longtin et al., 2018), clinical social work and psychotherapy (Romanelli et al., 2017; Romanelli \& Tishby, 2019), marketing skills (Mourey, 2020), public speaking competence (Casteleyn, 2019), and organisational creativity (West et al., 2017) have all reportedly benefitted from improvisation training.

What, then, are the core components of improvisation, specifically the set of skills that can be taught, learned, and applied in such diverse contexts? Some were already mentioned, such as spontaneity, collaboration, support, flexibility, trust, listening skills, and tolerating mistakes. However, no canonised curriculum for improvisation exists, although the method is continually evolving. Varying lists of basic principles of improvisation have been put forth (e.g. Aadland et al., 2017; Berk \& Trieber, 2009; Ratten \& Hodge, 2016; Trotter et al., 2013), with rough consensus outlining the core components. For example, Zondag et al. (2020) include trust, acceptance, attentive listening, spontaneity, storytelling, and nonverbal communication as the fundamentals of improvisation, while Schwenke et al. (2020) introduce rapid decision-making, risk-taking, presence, accepting ideas, trust, and collaboration as the set of primary skills and abilities.

Seppänen et al. (2019; see also Gillian-Daniel et al., 2020) argue that improvisation is influential in enhancing interpersonal confidence, that is, the belief regarding one's capabilities related to effective social interactions. Rather than the more general trait of self-confidence, interpersonal confidence refers to a situationally specific feature, focusing on social interactions. Additionally, rather than relating to trust among interacting partners as described by Dontsov and Perelygina (2014), here, interpersonal confidence refers to trust in oneself. Seppänen et al. distinguish the concepts of interpersonal skills and interpersonal confidence, since one might possess abundant knowledge about interpersonal behaviour as well as an ability to perform during social interactions while lacking the confidence to use these resources. However, interpersonal confidence might improve by providing training on the set of skills improvisation is likely to cultivate, such as listening and collaboration skills, flexibility, presence, trust, and tolerating mistakes. Seppänen et al. (2019) employed the 30-item Interpersonal Confidence Questionnaire (ICQ) developed by Novák $(2017,2020)$ and found that, relative to controls, participants with less interpersonal confidence initially benefitted more from applied improvisation intervention than participants with more initial interpersonal confidence.

Previous research on the impact of improvisation training relied on instruments measuring psychological factors such as self-concept (DeBettignies \& Goldstein, 2019); divergent thinking, uncertainty tolerance, and affective wellbeing (Felsman et al., 2020; Hainselin et al., 2018); self-esteem, self-efficacy, and resilience (Schwenke et al., 2020); or social skills, social anxiety, depression, hope, and creativity (Felsman et al., 2018). In addition, the physiological impact of improvisation has been studied (Seppänen et al., 2020) using heart rate, skin conductance, facial muscle activity, electrocortical activity, and stress hormone cortisol as indices of change in social stress following an improvisation intervention. All of these factors reveal interesting and important effects from the applied use of improvisation on human behaviour and wellbeing. However, a valid and reliable instrument developed to specifically measure the core components of improvisation would advance research and further our understanding of the impact of improvisation training. In addition to the aforementioned ICQ, the Improvisation Evaluation Scale (Berk \& Trieber, 2009) was developed to measure the self-reported effectiveness of improvisation exercises in a 
classroom context, while the Communication Skills Assessment Inventory (Becker, 2012) assesses preservice teachers' improvisation self-efficacy. Yet, these self-report scales remain unvalidated.

\subsection{Problem statement}

Theatrical improvisation includes a model of constructive communication which has been applied to education. However, no validated self-report instrument exists to measure the multidimensional skillset acquired through improvisation training.

\subsection{Research questions}

1) What are the psychometric properties of ICQ?

2) What are the immediate and long-term effects of improvisation training as measured using ICQ?

\subsection{Aim of study}

The aim of the current study is twofold. Since ICQ (Novák, 2017, 2020), developed to measure the effects of improvisation training using the core components of improvisation, remains unvalidated, we first aimed here to validate the questionnaire and examine its psychometric properties (composite and test-retest reliability and discriminatory power), as well as investigate the relationship of ICQ to other related psychological constructs. Second, we aimed to determine the immediate and long-term effects of improvisation training on interpersonal confidence using ICQ.

To investigate the relationship between self-esteem and interpersonal confidence, we used Rosenberg's Self-esteem Scale (RSE, Robins et al., 2001; Rosenberg, 1965). We hypothesised that a positive correlation exists between interpersonal confidence and self-esteem (one's perceived self-worth and self-acceptance), since one's thoughts and opinions of oneself include a social component (Gruenewald et al., 2004), possibly contributing to interpersonal confidence. We also contrasted interpersonal confidence with social phobia, since these two constructs should theoretically associate inversely with each other. We used the Mini-Social Phobia Inventory (Mini-SPIN, Connor et al., 2001; Ranta et al., 2012; Seeley-Wait et al., 2009) for the comparison, hypothesising that an inverse relationship exists between interpersonal confidence and social phobia. In terms of the effects of improvisation training, we hypothesised that interpersonal confidence increases following an improvisation intervention.

\section{Validation of the Questionnaire}

The development of ICQ was reported in Novák (2017). In summary, when constructing the questionnaire, ICQ statements were created by an improvisation instructor (second author) at the University of Turku in 2016 to assess the level of anxiety or confidence experienced during various social interactions. The statements reflected the components of social interactions, which improvisation training might hypothetically influence (e.g., listening and collaboration skills, flexibility, and status behaviour ${ }^{2}$ ). Both

\footnotetext{
${ }^{2}$ In improvisation, status behaviour is understood as various verbal and nonverbal behaviours indicating the social dominance of a person (Johnstone, 1985, pp. 33-39; Mason et al., 2014). Status behaviour is often subtle and subconscious, while status exercises during improvisation training help individuals become aware of and manipulate
} 
positive and negative statements were created, with a minimum of two items related to each component. The face and content validity of the items were evaluated by two professors of psychology, while a group of undergraduate students and persons with no experience in improvisation commented on the items. The unambiguity of the statements was examined, and poorly worded items were corrected. The final 30-item questionnaire consisted of randomly mixed positively and negatively worded statements rated on a Likert scale from 0 to 5 ( $0=$ strongly disagree, $5=$ strongly agree). The questionnaire was administered to 16 student teachers three times during a pilot improvisation intervention related to the development of ICQ (Novák, 2017). The negative ICQ statements were reversed to reflect positive statements and a summation variable was calculated producing each participant's mean ICQ score $(0-5)$. Higher scores indicated a higher interpersonal confidence.

\subsection{Sample}

For this study, a sample $(n=208)$ for validating ICQ was pooled from several improvisation courses (a 10-week, a 7-week, and four 5-week courses; see Figure 1). The data from the 10- and 5-week courses provided a new dataset, while the data from the 7-week course were utilised in Seppänen et al.'s (2019) intervention study. The entire sample consisted of undergraduate students recruited from nine universities in Finland (161 female, 40 male, and 7 other) ranging in age from 19 to 48 years $(M=26.87, S D \pm 6.4$ ). Participants enrolled either in an improvisation course aimed at enhancing social interaction skills or in a wait-listed control group. Students received course credit for participation in the study. All participants signed an informed consent form and completed an online demographic questionnaire, the original 30-item ICQ, and the Rosenberg's Self-esteem Scale among other questionnaires, which excluding the Mini-SPIN, lie beyond the scope of this specific study.

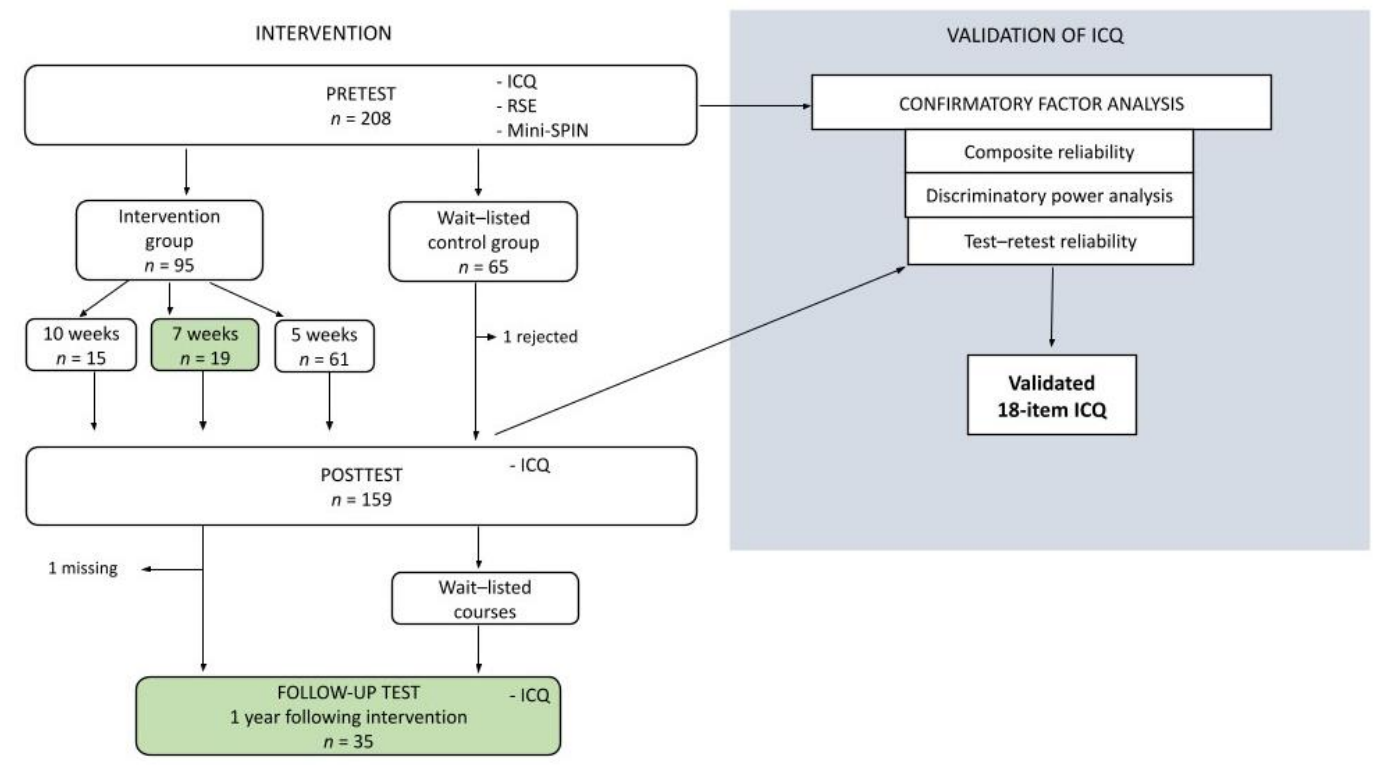

Figure 1. Study design and subsamples. Green shading indicates the subsample used in Seppänen et al., 2019

one's status behaviour. Therefore, status is not a permanent feature of an individual, but can be chosen and displayed according to situational requirements. 


\subsection{Confirmatory factor analysis (CFA)}

We used IBM's SPSS for Windows (version 27) and IBM's SPSS AMOS (version 27) for all statistical analyses. Based on the literature and their professional experience, the first and second authors constructed a measurement model which clustered the 30 statements of ICQ along 8 dimensions (factors) reflecting the components of improvisation in the context of social interactions. These factors were labeled as follows: 1. performance confidence, 2. flexibility, 3. listening skills, 4. tolerance of failure, 5. trust, 6. collaboration motivation, 7. status behaviour, and 8. presence. Table 1 shows this hypothesised factor structure of ICQ. A confirmatory factor analysis (CFA) was performed to validate the eight-factor measurement model of the questionnaire.

Table 1. The hypothesised factor structure of the Interpersonal Confidence Questionnaire (ICQ)

1. Performance confidence

28. I am afraid of making mistakes when I perform.*

3. When I am delivering a presentation, I focus primarily on keeping myself together.*

27. I am anxious about saying something wrong.*

4. During a presentation, it disturbs me if my cheeks blush or my hands shake.*

5. I often contemplate for a long time what I have spoken out loud somewhere.*

2. Flexibility

20. I am open to change.

22. I usually want things to be done in the most familiar way.*

13. I take risks in my life.

7. I am afraid of sudden changes to my plans.*

25. I have the courage to take chances when dealing with new situations.

15. I am confident for the future; things tend to work out.

3. Listening skills

6. When I talk to others, I take the other speakers into account.

21. I am a good listener.

12. I give other people positive feedback.

16. Usually, I do not listen to what other people talk about.*

9. I sometimes talk over others and do not wait for my turn.*

4. Tolerance of failure

10. I easily take things personally.*

11. I find it difficult to receive criticism.*

1. I do not mind what other people think of me.

14. If I have made a mistake, I take it with a sense of humor.

5. Collaboration motivation

2. I prefer to work within a team.

18. I find it easier to work alone than with someone.*

6. Trust

8. I enjoy attention from other people.

30 . I can easily trust strangers.

29. I have the courage to throw myself into situations that require physical contact.

7. Status behaviour

24. I generally adjust my opinions during group work.

19. I usually assume the leading role in a group.

17. I often make sure that I have done things correctly.*

8. Presence

23. I find it difficult to focus on being present in the here and now.*

26. I can easily concentrate on the task at hand.

Note: *Scale to be reversed. 
Multiple fit indices were used to estimate the model fit using the following criteria: 1. the ratio of chi-square to degrees of freedom $\left(\chi^{2} / \mathrm{df}\right.$, between 1 and 3$) ; 2$. the Comparative Fit Index (CFI, > 0.90); 3. the Tucker Lewis Index (TLI, > 0.90); 4. the root mean square error of approximation $(\mathrm{RMSEA},<0.06)$; and 5. the standardised root mean square residual (SRMR, $<0.05)$. Factor loadings $<0.5$ were discarded from the model as well as items with standardised residual covariances exceeding 1.96 (Cabrera-Nguyen, 2010), which resulted in the omission of 10 items. Since only one item representing the factors of trust and status behaviour, respectively, remained, these individual items were omitted as well ${ }^{3}$. The final 18-item, 6-factor measurement model of ICQ (Figure 2) demonstrated a satisfactory model fit $\left(\chi^{2} / \mathrm{df}=1.52\right.$, CFI $=$ $0.94, \mathrm{TLI}=0.93, \mathrm{RMSEA}=0.05, \mathrm{SRMR}=0.05)$.

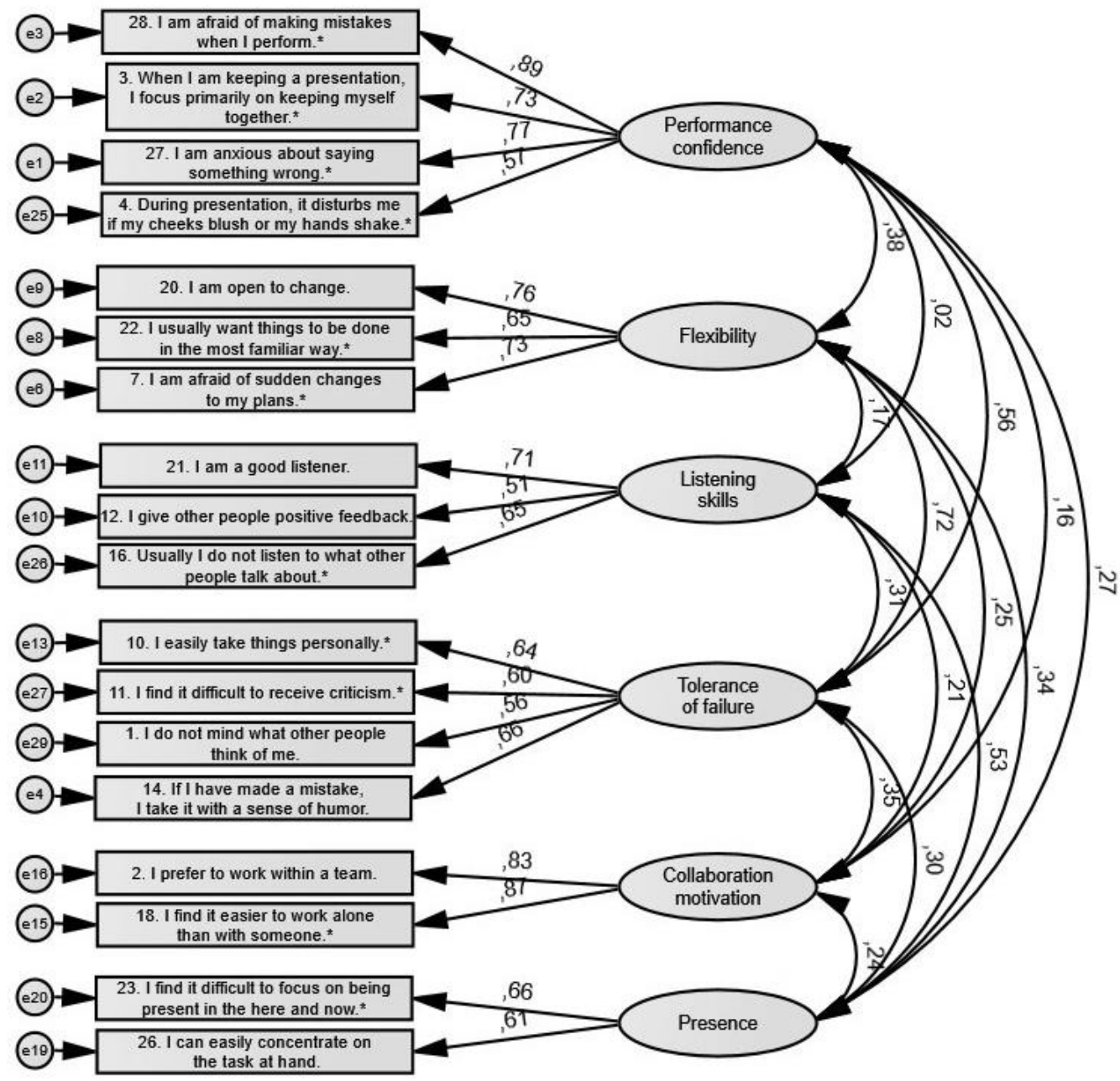

Figure 2. The 18-item, 6-factor measurement model of the Interpersonal Confidence Questionnaire (ICQ). The small circles on the left signify the error terms, the squares provide the original individual statements, and the ovals signify the ICQ factors. Factor loadings are depicted with arrows from factors to statements, and the correlations between factors are indicated by the curved multidirectional arrows on the right

\footnotetext{
${ }^{3}$ One item could be representative of a specific factor, assuming a strong theoretical justification. Here, Q29, which focused on physical contact, was not deemed adequate to represent trust, nor did Q19, indicative of a high status, represent the entire scope of status expression. Improvisation training does not aim to enhance either high- or lowstatus behaviour but seeks instead to improve the flexibility of status behaviour depending on contextual requirements.
} 


\subsection{Composite reliability}

The internal consistency of the six factors were examined by calculating their composite reliability (Raykov, 1997) using Microsoft Excel. Excluding presence, the factors reached the cut-off value of 0.60 (Table 2), indicating an adequate internal consistency.

Table 2. Composite reliability of the ICQ factors

\begin{tabular}{ll}
\hline Factor & Composite reliability \\
\hline Performance confidence & 0.83 \\
Flexibility & 0.76 \\
Listening skills & 0.66 \\
Tolerance for failure & 0.71 \\
Collaboration motivation & 0.84 \\
Presence & 0.57 \\
\hline
\end{tabular}

\subsection{Test-retest reliability}

In total, 65 control group participants repeated ICQ approximately 8 weeks $(\mathrm{M}=8.5, \mathrm{SD} \pm 3.7)$ after the initial administration. We used the Spearman's correlation analysis to establish the test-retest reliability (i.e., stability over time) of ICQ between measurements. The Spearman's rho for the 18-item questionnaire $(\mathrm{rs}=0.853, \mathrm{p}<0.01)$ revealed a strong association between measurements.

\subsection{Discriminatory power}

The discriminatory power of ICQ was examined using the contrasting groups method following Richaud et al. (2017). We conducted an independent samples t-test to determine if a difference in means existed for participants with the highest interpersonal confidence scores (upper quartile) relative to participants with the lowest interpersonal confidence scores (lower quartile). The lower and upper quartiles differed in the 18-item ICQ $[t(96)=-24.691, p<0.001]$.

\subsection{Relationship of interpersonal confidence between self-esteem and social phobia}

The relationship between interpersonal confidence and self-esteem was determined using the Pearson's correlation coefficient. A positive correlation was observed between the 18-item ICQ and Rosenberg's Self-esteem Scale $(r=0.550, p<0.001)$.

A subsample (102 female, 28 male, and 6 other; age $M=26.6 ; S D \pm 6.2$ ) of the study also completed the Mini-Social Phobia Inventory (Mini-SPIN). A Pearson's correlation coefficient analysis revealed a negative correlation between the 18-item ICQ and Mini-SPIN $(r=-0.661, p<0.001)$.

\section{Impact of Improvisation Training Measured by the 18-Item ICQ}

\subsection{Measures}

The original 30-item ICQ was administered at three time points (T1, pretest; T2, posttest; and T3, follow-up test one year following the intervention). The impact of the improvisation training was examined 
utilising the 18-item ICQ and its factors performance confidence, flexibility, listening skills, tolerance of failure, collaboration motivation, and presence.

\subsection{Participants}

Two subsamples of the sample utilised in CFA were used to study the impact of improvisation training (Figure 1). First, to test the immediate effect of improvisation training, we used a subsample $(n=$ 160) consisting of those participants who completed ICQ both before (T1) and after (T2) improvisation training. Participants (124 female, 32 male, and 4 other; ranging in age from 19 to 48 years $[M=26.6, S D$ $\pm 6.3]$ ) were pooled from several improvisation courses conducted by the first and second authors. The intervention group $(n=95)$ participated in a 10-week $(n=15)$, a 7 -week $(n=19)$, or 5 -week $(n=61)$ improvisation course. The wait-listed control group $(n=65)$ completed ICQ for the second time after equivalent periods ( 10 weeks, $n=15$; 7 weeks, $n=18$; and 5 weeks, $n=32$ ).

Second, to test the long-term effects of improvisation training, we used a follow-up subsample consisting of participants who completed ICQ before (T1), after (T2), and one year (T3) following the improvisation intervention $[n=35 ; 31$ female, 3 male, and 1 other; ranging in age from 20 to 40 years $(M$ $=27.6, S D \pm 6.6)]$. The intervention group of this subsample participated in a 7-week (17.5 h) improvisation course, the results of which appear elsewhere (Seppänen et al., 2019). The control group participated in a shorter two-day $(8 \mathrm{~h})$ improvisation course after the intervention study. Thus, the data from T1 and T2 were the same as that in Seppänen et al. (2019), analysed here using the 18-item ICQ. The follow-up data (T3) relied on a new dataset.

\subsection{Interventions}

Following the pretest, two teachers specialised in theatrical improvisation conducted the intervention (a 7-week course by the first author and 5- and 10-week courses by the second author). Lessons lasted 2.5 hours each for the 7-week course and 2 hours each for the 5- and 10-week courses. Participants were taught the basics of improvisation, including spontaneity, presence, tolerating mistakes, accepting and continuing ideas, group creativity, and status expression (interpersonal power and nonverbal interaction, such as eye contact, facial expressions, gestures, and body posture) (Barrett, 1998; Drinko, 2013b; Johnstone, 1985, 1999; Lobman, 2006; Sawyer, 2004, 2012; Spolin, 1999; Vera \& Crossan, 2005). More specific details regarding the 7-week improvisation training appear in Seppänen et al. (2019). The most important content was comparable to the 5-week course. The 10-week course targetted student teachers, during which the three last meetings consisted of teacher students themselves teaching improvisation exercises to one another.

\subsection{Data analyses}

Statistical analyses were performed using IBM's SPSS for Windows (version 27.0). The negatively worded statements were converted to positive statements, and summation variables of the 18-item ICQ and its factors were calculated. An independent samples t-test was performed to test the age difference between research groups. To identify the immediate effects of the improvisation intervention on interpersonal 
confidence, performance confidence, flexibility, listening skills, tolerance of failure, collaboration motivation, and presence, we conducted a two-way analysis of variance (ANOVA) for mixed measures including TIME (pretest and posttest) as a within-group factor and GROUP (intervention group and control group) as a between-group factor. Paired-samples t-tests were performed as follow-up tests. We also used Bonferroni corrections to address the problem of multiple comparisons. We set the alpha level at 0.05 for all statistical analyses, while estimates of the effect size are reported using the partial eta squared $\left(\eta p^{2}\right)$.

To identify the long-term effects of the improvisation intervention, we adopted the JohnsonNeyman procedure (JN) (Johnson \& Neyman, 1936; Potthoff, 1964; Preacher et al., 2006) following Seppänen et al. (2019). JN determines the levels of the pretest where the posttest values differ between research groups, producing a continuous 'region of significance' (D'Alonzo, 2004; Ji, 2016; Johnson, 2016; Tunca, 2016). Since Seppänen et al. found a heterogeneous treatment effect from the improvisation intervention benefiting those with lowest pretest ICQ scores most, we used the same JN method to study whether this effect remained one year later. A CAHOST-Excel workbook developed by Carden et al. (2017) was used to calculate the JN region of significance.

\subsection{Results}

An independent samples t-test detected no difference related to the mean age between the intervention and control groups at the pretest $[t(160)=-0.274 ; p=0.785]$.

\subsubsection{Immediate impact of improvisation training}

To study the immediate impact of improvisation training, an ANOVA for mixed measures revealed a TIME $x$ GROUP interaction for the 18-item ICQ $\left[F(1,158)=12.400 ; p<0.001 ; \eta p^{2}=0.073\right]$ and for the factors of performance confidence $\left[F(1,158)=13.858 ; p<0.001 ; \eta \mathrm{p}^{2}=0.081\right]$ and tolerance of failure $\left[F(1,158)=5.525 ; p=0.020 ; \eta \mathrm{p}^{2}=0.034\right]$. For flexibility, there was a marginally significant interaction $\left[F(1,158)=3.238 ; p=0.074 ; \eta \mathrm{p}^{2}=0.020\right]$. Adjacent paired t-tests indicated that interpersonal confidence (Figure 3a) increased from the pre- to the posttest for the intervention group [t(94) $=5.377 ; p<0.001]$, but not for controls $[t(64)=0.621 ; p=0.537]$, a finding similar to performance confidence (Figure $3 \mathrm{~b}$ ) [intervention group: $t(94)=5.752 ; p<0.001$; controls $t(64)=0.766 ; p=0.446$ ] and tolerance of failure (Figure 3c) [intervention group: $t(94)=3.607 ; p<0.001$; controls: $t(64)=0.338 ; p=0.736$ ]. For collaboration motivation (Figure 3f), there was a significant main effect for $\operatorname{TIME}[F(1,158)=12.208 ; p$ $\left.=0.001 ; \eta p^{2}=0.072\right]$, but no interaction for GROUP, indicating that the level of collaboration motivation increased from the pre- to posttest irrespective of the research group. 
Selection and peer-review under responsibility of the Organizing Committee of the conference

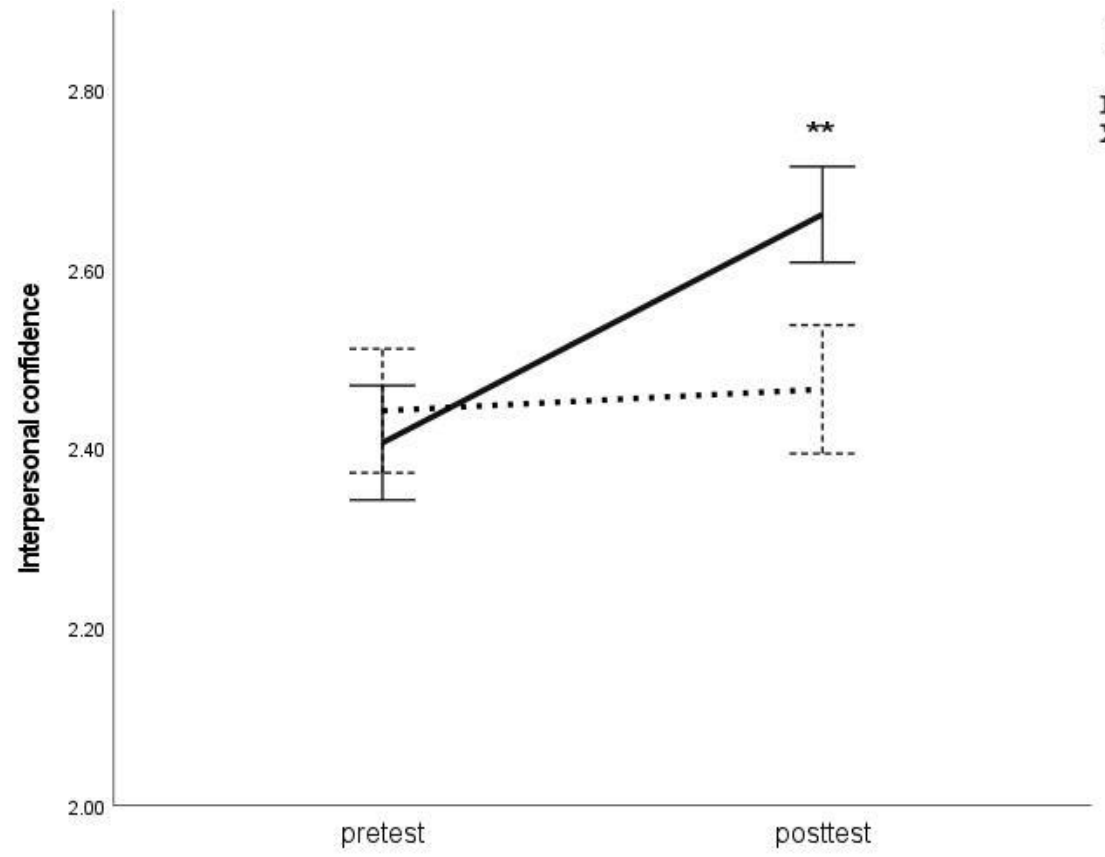

Research group

I improvisation control

(a)

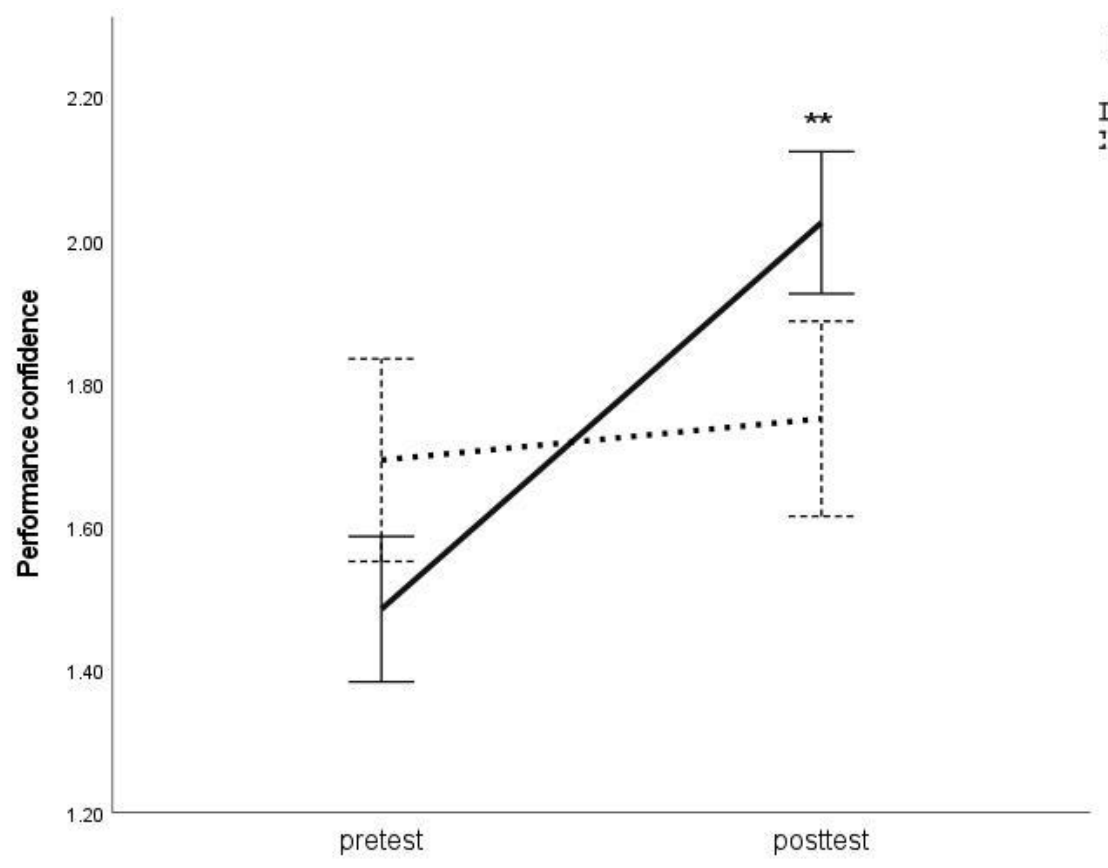

Research group

I improvisation

control

(b) 
Selection and peer-review under responsibility of the Organizing Committee of the conference

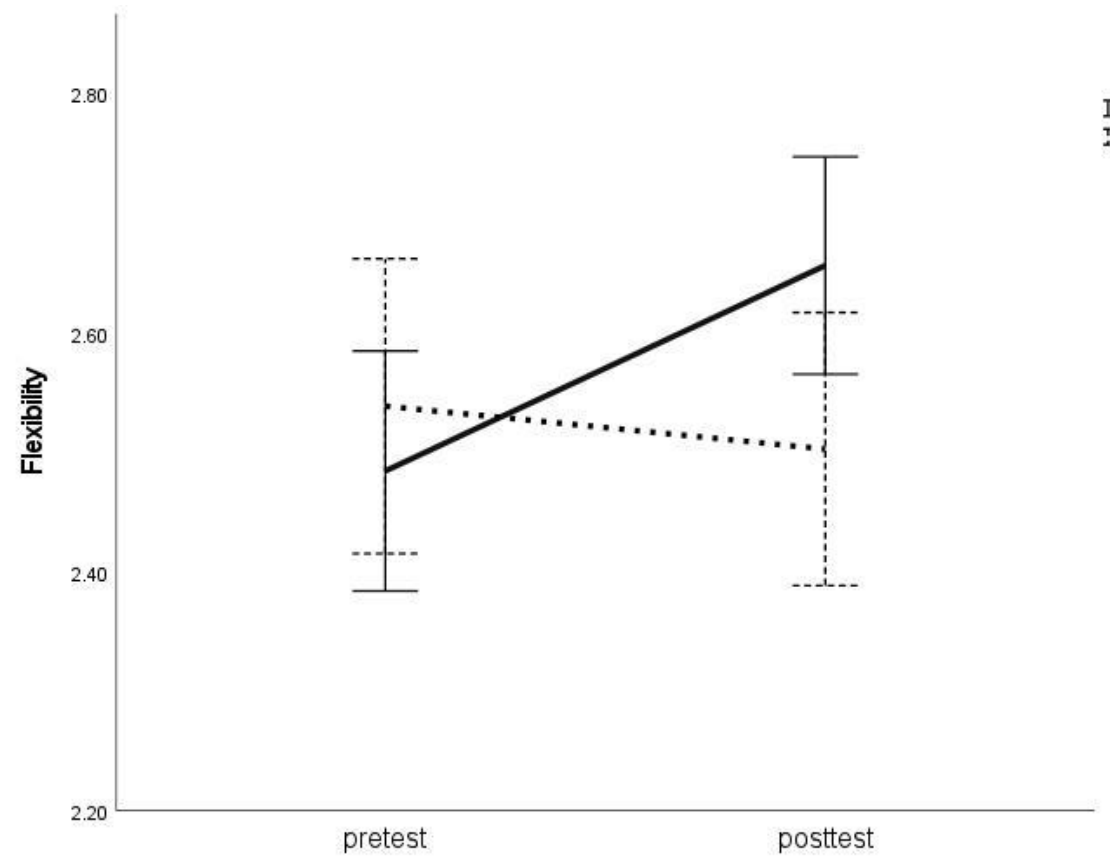

Research

group

I improvisation

control

(c)

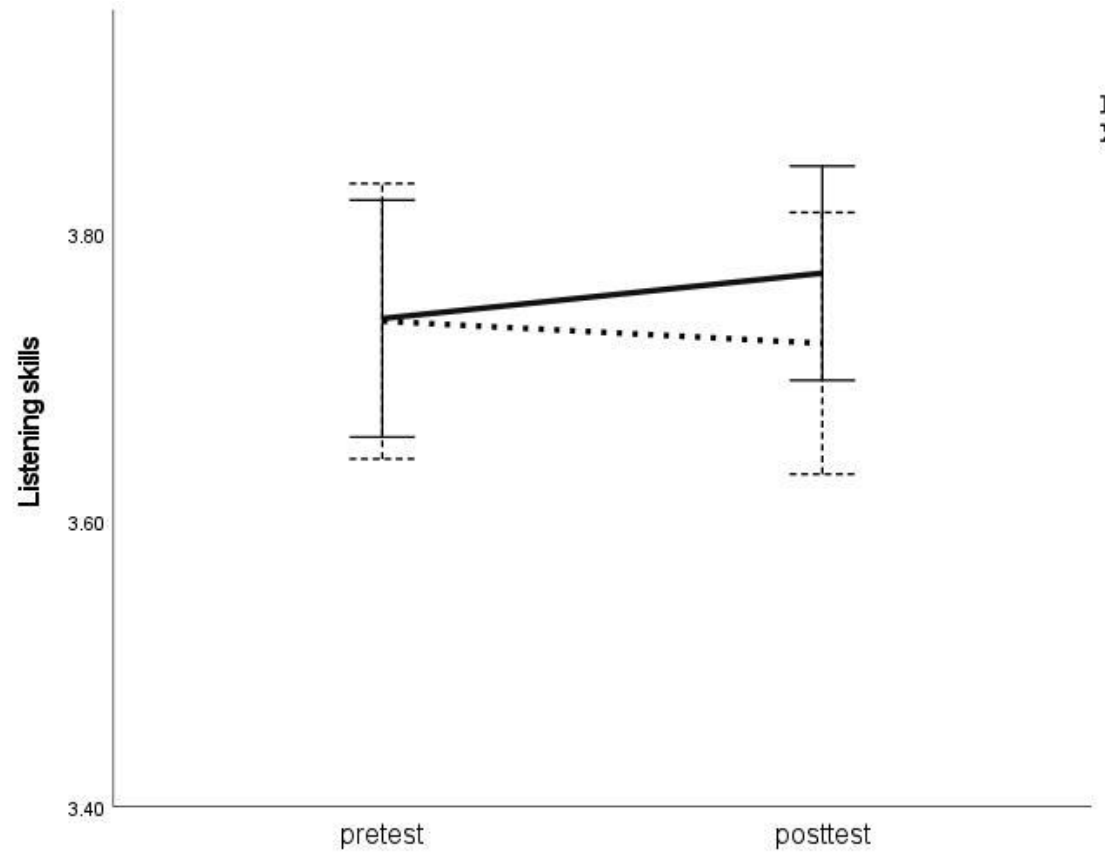

Research

group

I improvisation

control

(d) 
Selection and peer-review under responsibility of the Organizing Committee of the conference

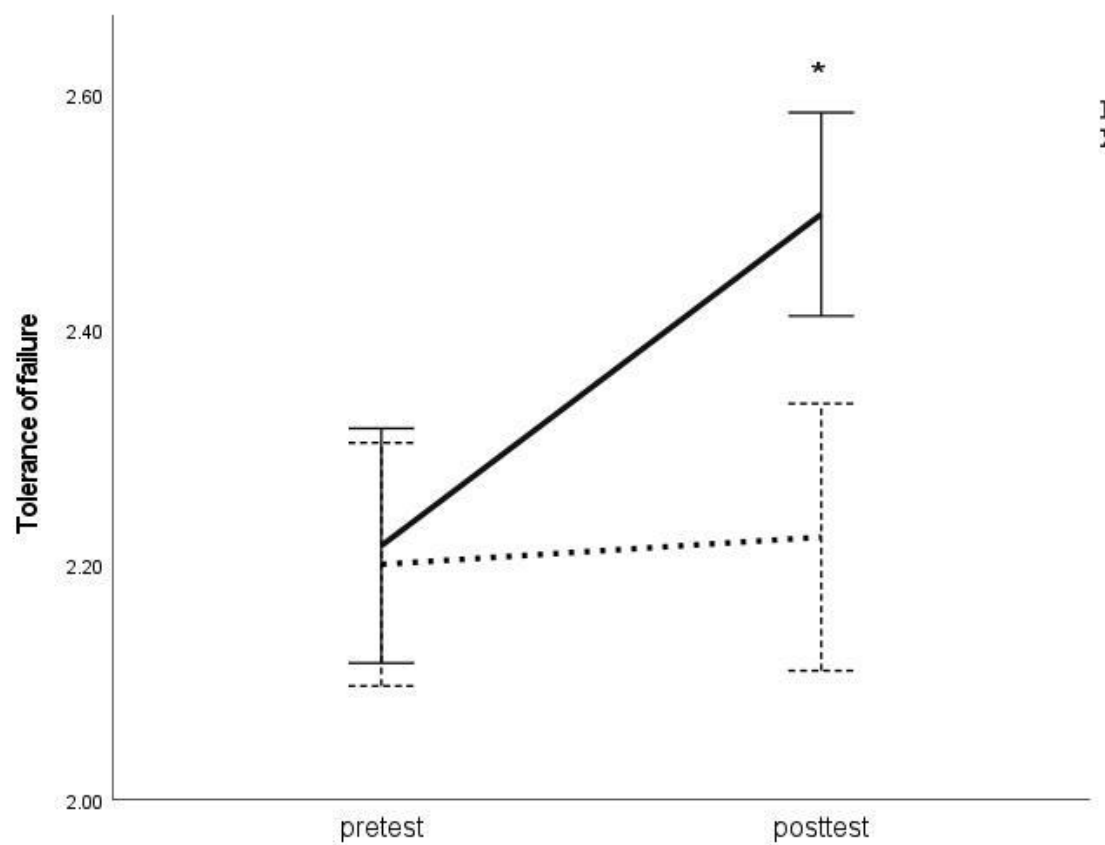

Research

group

I improvisation

(e)

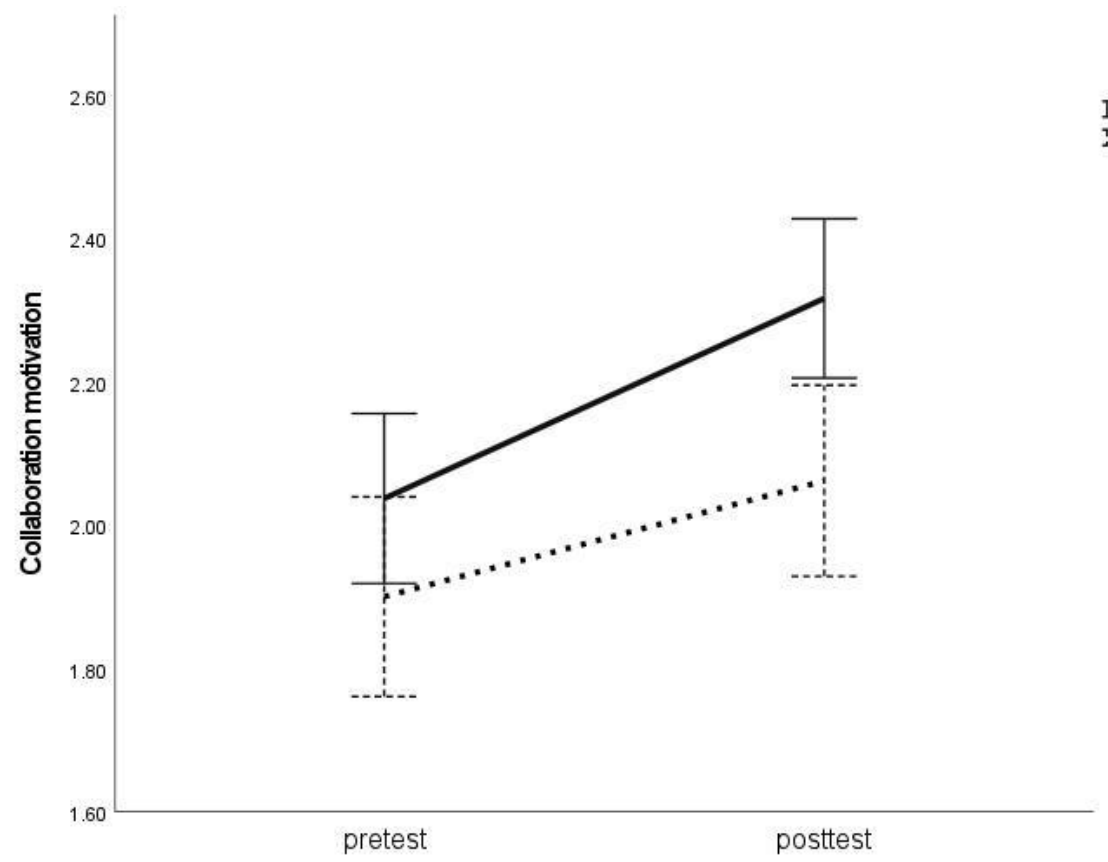

Research

group

I improvisation

control

(f) 


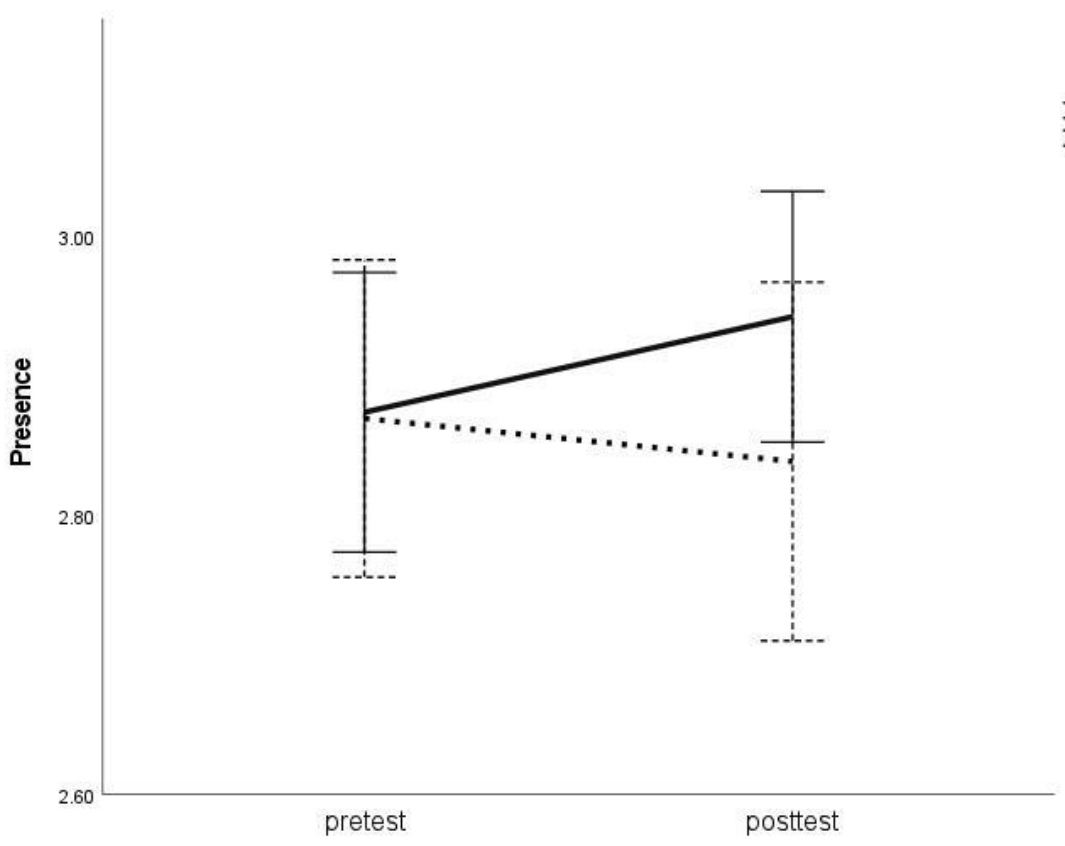
Research group
I improvisation
I control

(g)

Figure 3. a) Interpersonal confidence as measured by the a) 18 -item ICQ, b) performance confidence, c) flexibility, d) listening skills, e) tolerance of failure, f) collaboration motivation, and g) presence before and after improvisation training. ${ }^{*} p<0.001,{ }^{*} p<0.05$; error bars: $\pm 1 \mathrm{SE}$

We conducted an additional ANOVA for repeated measures to identify whether the pretest scores differed from one another, since differential treatment effects among factors raised the question of the impact of their initial level. The ANOVA revealed a main effect for the pretest scores $[F(6,954)=124,644$; $\left.p<0.001 ; \eta p^{2}=0.439\right]$ and adjacent pairwise comparisons indicated that the pretest differed $(p<0.05$ for all) excluding ICQ versus flexibility $(p=1.00)$ and collaboration motivation versus tolerance of failure $(p$ $=0.549)$.

\subsubsection{The long-term impact of improvisation training}

Table 3 provides the regions of significance for the differences between experimental groups revealed through the $\mathrm{JN}$ analyses.

Table 3. Johnson-Neyman regions of significance for the differences between experimental group

\begin{tabular}{lll}
\hline & \multicolumn{2}{l}{ Region of significance } \\
\cline { 2 - 3 } & T1 vs. T2 & T1 vs. T3 \\
\hline Interpersonal confidence & $1.23-2.74$ & - \\
Performance confidence & $0.04-2.51$ & $<1.96$ \\
Flexibility & - & - \\
Listening skills & - & - \\
Tolerance of failure & - & - \\
Collaboration motivation & - & - \\
Presence & - & - \\
\hline
\end{tabular}

Note. The range of the Interpersonal Confidence Questionnaire is $0-5$. Region of significance reveals the range of pretest values, where the difference between research groups at posttest (T2) and follow-up test (T3) is significant.

Abbreviations: $\mathrm{T} 1=$ pretest, $\mathrm{T} 2=$ posttest, $\mathrm{T} 3=$ follow-up test 
The JN analysis for the 18-item ICQ at T1 versus T2 (Appendix B1a) indicated a significant increase in interpersonal confidence relative to controls among participants with pretest scores falling within the range of 1.23 to $2.74(n=8)$, but not for those with lower $(n=1)$ or higher pretest scores $(n=10)$. No region of significance was observed at $\mathrm{T} 1$ versus $\mathrm{T} 3$ (Appendix B1b). The mean values for interpersonal confidence at the pre-, post-, and follow-up tests appear in Figure 4.

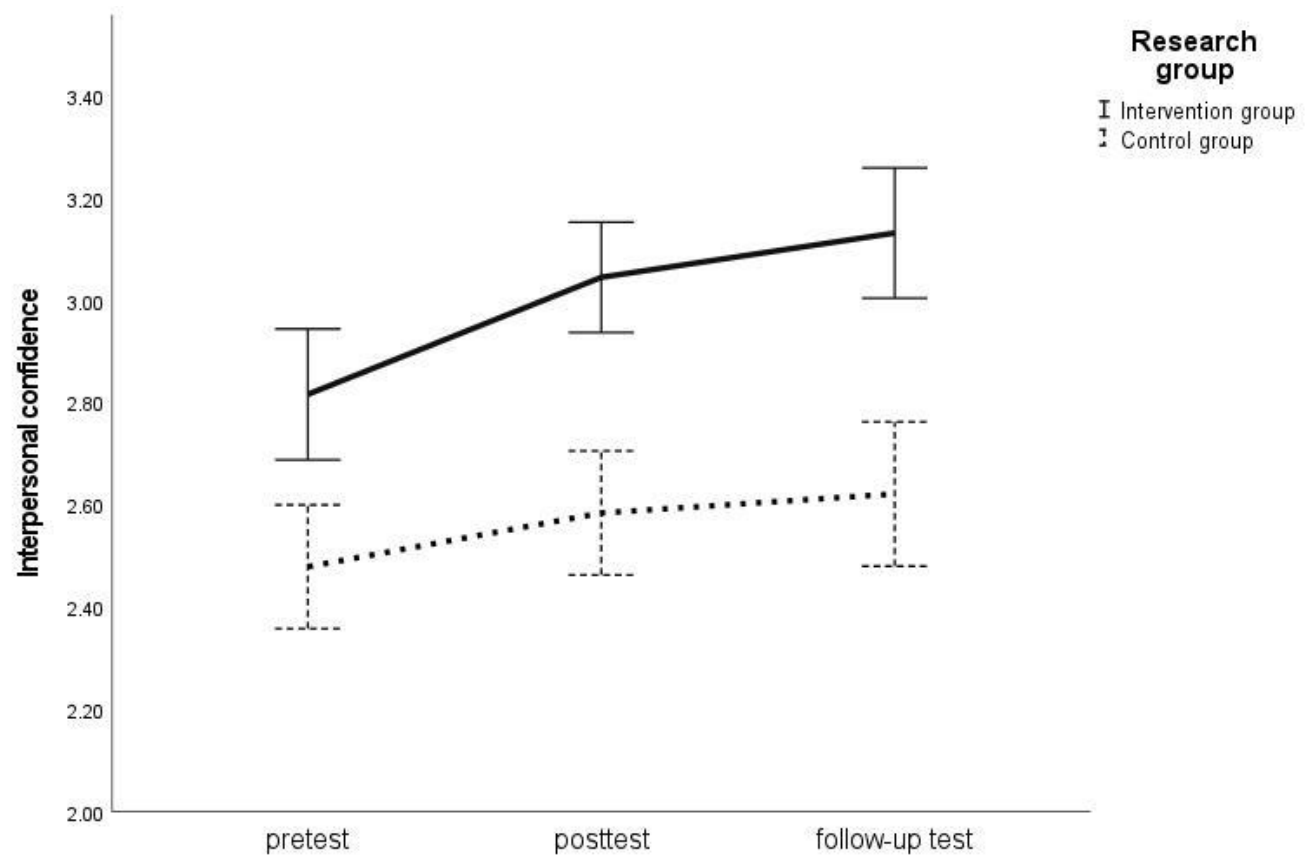

Figure 4. Mean values of interpersonal confidence at the pre-, post-, and follow-up tests (one year). Error bars: $\pm 1 \mathrm{SE}$

The JN analysis for the ICQ factor performance confidence at T1 versus T2 (Appendix B2a) indicated a significant increase relative to controls for participants, with the pretest performance confidence score ranging from 0.04 to $2.51(n=16)$, excluding those with lower $(n=1)$ or higher pretest scores $(n=2)$. At T1 versus T3 (Appendix B2b), participants with a low pretest performance confidence $(<1.96, n=14)$ exhibited an increased performance confidence relative to controls, which was not found among those with high pretest scores $(n=4)$. These results indicate that, relative to controls, the increase in performance confidence was significant for participants in the intervention group with low pretest scores and that this effect persisted for one year. Mean values for performance confidence at the pre-, post-, and follow-up tests appear in Figure 5. 


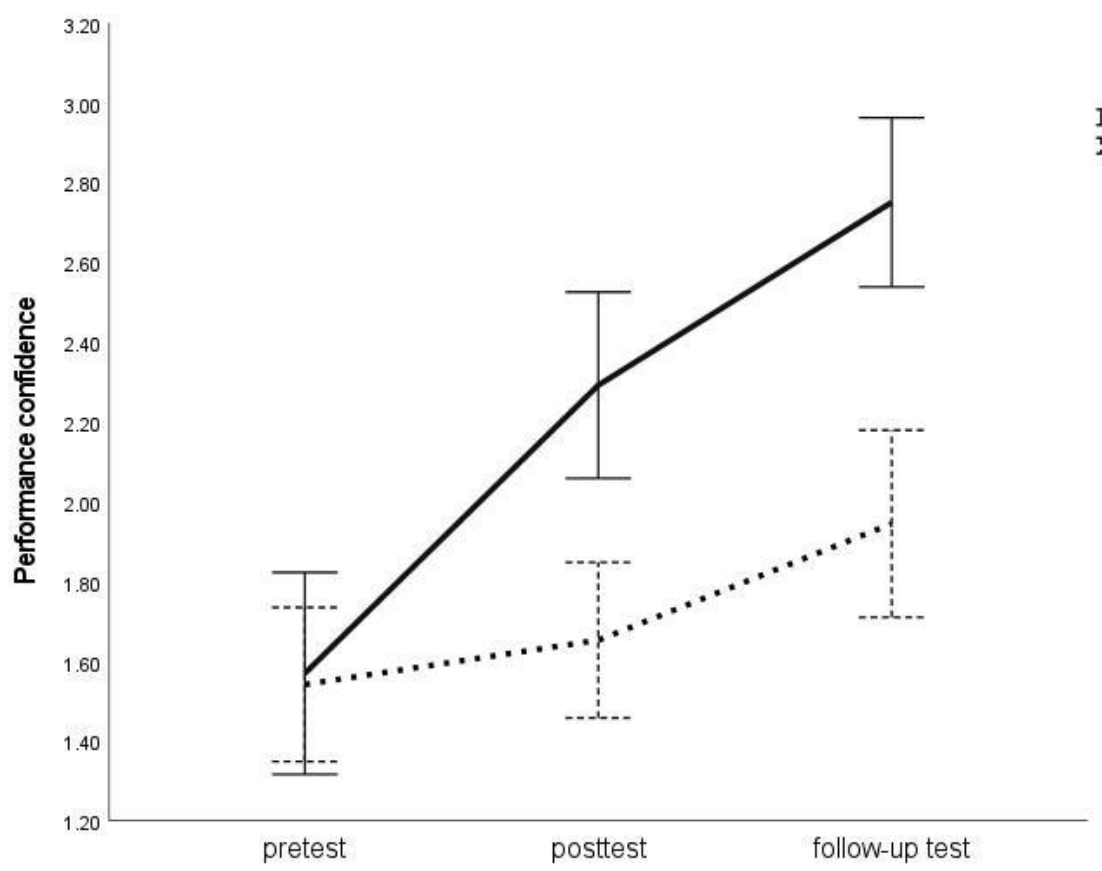

\section{Research}

group

I Intervention group

I Control group

Figure 5. Mean values for performance confidence at the pre-, post-, and follow-up tests (one year). Error bars: $\pm 1 \mathrm{SE}$

The JN analysis identified no areas of significance for the factors flexibility, listening skills, tolerance of failure, collaboration motivation, and presence, indicating no differences between the research groups at $\mathrm{T} 1$ versus $\mathrm{T} 2$ or at $\mathrm{T} 1$ versus $\mathrm{T} 3$.

\section{Discussion}

To our knowledge, no validated self-assessment instruments exist to measure the multidimensional skill set acquired through improvisation training. Therefore, this study addressed this methodological gap by validating the Interpersonal Confidence Questionnaire (ICQ), developed by Novák $(2017,2020)$ to evaluate the impact of improvisation training. Additionally, we investigated the immediate and long-term impact of improvisation interventions using ICQ.

The concept of interpersonal confidence refers to a situationally specific context, focusing on social interactions rather than on the more general trait of self-confidence (Seppänen et al., 2019). Similarly, tools such as the Scale of Perceived Social Self-Efficacy (Smith \& Betz, 2000) and the Scale of Perceived Empathetic and Social Self-Efficacy (Di Giunta et al., 2010) measure the social dimension of self-efficacy in general. Self-efficacy, a concept developed by Bandura $(1977,1982)$, refers to the belief in one's capacity to manage environmental demands and perform successfully in a given task (e.g., for family-teacher communication, see De Coninck et al. (2020); for negotiating during role-play simulation, see Duchatelet et al. (2021)). Accordingly, ICQ targets the measurement of an individual's perceived capability related to effective social interactions rather than possessing social skills. 


\subsection{Psychometric properties of ICQ}

The results of this study provide an 18-item scale of interpersonal confidence across six factors: performance confidence, flexibility, listening skills, tolerance of failure, collaboration motivation, and presence. The composite reliability of the factors was adequate, excluding the 0.57 value for the factor presence, which approached the cut-off limit of 0.6. This factor might benefit from the inclusion of additional statements to assess presence in ICQ. The level of interpersonal confidence remained stable across the relatively long test-retest interval of 8 weeks, indicating a high test-retest reliability. ICQ also exhibited a discriminatory power since the mean values between the highest and lowest percentiles differed significantly. The Pearson's correlation coefficients revealed a positive correlation between interpersonal confidence and self-esteem, measured using the Rosenberg Self-Esteem Scale. However, the medium correlation $(r=0.550)$ might indicate that the Rosenberg Self-Esteem Scale may assess more general and ICQ more situation-specific and socially focused aspects of self-related opinions. Finally, interpersonal confidence and social phobia, measured using Mini-SPIN (Connor et al., 2001; Ranta et al., 2012; SeeleyWait et al., 2009), revealed an expected inverse relationship.

\subsection{Impact of improvisation training on interpersonal confidence}

We used the 18-item ICQ to study the immediate and long-term impact of improvisation training on interpersonal confidence and its factors performance confidence, flexibility, listening skills, tolerance of failure, collaboration motivation, and presence. As expected, our results revealed improvements to interpersonal confidence, performance confidence, and tolerance of failure for the improvisation group relative to controls at the posttest. The improvement in flexibility was marginally significant. Interestingly, collaboration motivation increased irrespective of improvisation training. One possible explanation for this unexpected result relates to the overall collaboration experience, since university training might have included group assignments for all students during the research period. Thus, the control group also might have gained experience with and motivation for collaboration through group work. Another explanation relates to the questionnaire itself. Collaboration motivation was measured using two statements, whereas performance confidence and tolerance of failure relied on four statements, respectively. Perhaps these fouritem factors more accurately assessed the feature and its change following the intervention. This observation might explain also the missing result for the two-item factor presence, which showed the lowest composite reliability score. In terms of listening skills, the lack of the hypothesised increase in the improvisation group might relate to the ceiling effect. In this case, the pretest score for listening skills was relatively high $(M=3.7 ; S D \pm 0.80)$ using a Likert scale ranging from 0 to 5 . Furthermore, the initial level for listening skills was highest relative to other factors. Thus, it is possible that there was less potential for improvement within listening skills.

Results from the 18-item ICQ agreed with previously reported pretest-posttest findings measured using the original 30-item ICQ (Seppänen et al., 2019). At the posttest, both scales detected a differential effect from improvisation training on interpersonal confidence resulting in a stronger benefit to participants with low pretest scores. However, this effect disappeared one year later. Perhaps the development of interpersonal confidence ceased once improvisation training ended (none of the participants reported 
attending improvisation courses following the intervention). Yet, since the wait-listed control group participated in a shorter improvisation course following the study period, attending a course possibly confounded our results by diminishing the between-group difference.

In terms of ICQ factors, improvisation training enhanced performance confidence relative to the control group, and this between-group difference persisted for one year. Again, participants with low initial levels of performance confidence gained the most benefit from the intervention. For the other factors, no between-group differences at the post- nor follow-up tests were identified within this subsample. Possibly, the statistical power was insufficient here to reveal intervention effects.

Why then did the improvisation intervention influence performance confidence? Participant motivation might explain this outcome. The improvisation course advertisement mentioned a special target group, 'persons struggling with performance anxiety', although other interested individuals were also accepted into the course (excluding those with previous experience with improvisation training). Perhaps, the primary motivation for attending the improvisation course was to alleviate performance anxiety, which might have led participants to challenge themselves to take risks encouraged by the psychologically safe atmosphere and supportive improvisation group, eventually leading to an increased performance confidence. Some support for this explanation is provided by the lower initial level of performance confidence versus other factors. Thus, there might have been more potential for a change in performance confidence relative to other factors. This finding agrees with studies on the impact of improvisation training (DeBettignies \& Goldstein, 2019) and drama education (Wright, 2006) on school children's self-concept, that is, how students perceive their status and abilities. They found a positive training effect, but only among children who began with relatively lower levels of self-concept. While self-concept represents a more general construct than performance confidence, these results suggest that the gains from interventions may be related to the initial level of the targeted psychological construct.

Additionally, the enhanced performance confidence endured for one year regardless of the discontinuation of improvisation training, possibly reflecting a transfer effect. Student teachers confront performance situations frequently in their studies (e.g., presentations and teaching practice). Perhaps, improved performance confidence transferred from the improvisation training context to their everyday life-performance situations, such that the benefits persisted.

The results of this study offer practical implications for fields where interpersonal competencies are required, such as in the context of education. According to Coppens (2002), a teacher should establish a safe space where pupils can experiment and learn, and be continually ready to integrate unexpected contributions from pupils and the environment. While planning lessons is a crucial component of a teacher's professional skills, responsiveness plays an equally important role - that is, readiness to abandon a plan and intuitively shift the course of a lesson according to the situational challenges. This situational sensitivity and responsiveness as well as intuitive thinking can be practised through applied improvisation (Aadland et al., 2017). As Sawyer (2011) states, great teaching requires both structuring elements and improvisational brilliance. 


\subsection{Limitations of the study}

This study has several limitations. Further research is needed to investigate the psychometric qualities of ICQ in more detail. As such, future research should examine the convergent, divergent, and predictive validity of ICQ. In addition, it would be interesting to examine the association between interpersonal confidence and interpersonal communication competence (Rubin \& Martin, 1994), a close yet more general concept reflecting aspects of interpersonal behaviour. Moreover, the results here should be replicated and extended to different cultures, since these results cannot be generalised beyond Finnish culture. We present here an English translation of the scale (Appendix A1, in Finnish see Appendix A2), which requires validation among international respondents. Despite these limitations, the present study contributes to the literature in educational research and offers practical implications for fields where interpersonal competencies are required.

\subsection{Conclusions}

This study provides initial evidence of the validity and reliability of ICQ as a self-report measure of interpersonal confidence. In addition to providing a useful tool ${ }^{4}$ to determine the impact of improvisation training in future, ICQ may be used as a screening tool to identify individuals who might benefit the most from the training - that is, persons with low interpersonal confidence. Our results demonstrated that improvisation training promoted interpersonal confidence, performance confidence, and tolerance of failure relative to a control group. One year later, performance confidence persisted at a higher level than that found among the control group. These results extend our understanding of the impact of improvisation training, demonstrating that a relatively short improvisation intervention might enhance interpersonal confidence, specifically among those who most need it.

\section{Acknowledgments}

Sirke Seppänen received financial support from the Doctoral School in Humanities and Social Sciences at the University of Helsinki for the presentation of this paper at the $12^{\text {th }}$ ICEEPSY 2021 online conference. The authors declare that they have no conflict of interest. The funding agencies were not involved in any part of this study. We would like to thank Vanessa Fuller for English-language proofreading of the manuscript.

\section{References}

Aadland, H., Espeland, M., \& Arnesen, T. E. (2017). Towards a typology of improvisation as a professional teaching skill: Implications for pre-service teacher education programmes. Cogent Education, 4(1), 1295835. https://doi.org/10.1080/2331186X.2017.1295835

Bandura, A. (1977). Self-efficacy: Toward a unifying theory of behavioral change. Psychological Review, 84(2), 191-215. https://doi.org/10.1037/0033-295X.84.2.191

Bandura, A. (1982). Self-efficacy mechanism in human agency. American Psychologist, 37(2), 122-147. https://doi.org/10.1037/0003-066X.37.2.122

\footnotetext{
${ }^{4}$ Usage of ICQ is possible and most welcome using this article as a reference.
} 
Barrett, F. J. (1998). Coda-Creativity and Improvisation in Jazz and Organizations: Implications for Organizational Learning. Organization Science, 9(5), 605-622. https://doi.org/10.1287/orsc.9.5.605

Becker, T. (2012). Evaluating Improvisation As A Technique For Training Pre-service Teachers For Inclusive Classrooms. [Doctoral dissertation, University of Central Florida]. Electronic Theses and Dissertations, 2004-2019. 2491. https://stars.library.ucf.edu/etd/2491

Benjamin, S., \& Kline, C. (2019). How to yes-and: Using improvisational games to improv(e) communication, listening, and collaboration techniques in tourism and hospitality education. Journal of Hospitality, Leisure, Sport \& Tourism Education, 24, 130-142. https://doi.org/10.1016/j.jhlste.2019.02.002

Berk, R. A., \& Trieber, R. H. (2009). Whose Classroom Is It, Anyway? Improvisation as a Teaching Tool. Journal on Excellence in College Teaching, 20(3), 32.

Cabrera-Nguyen, P. (2010). Author Guidelines for Reporting Scale Development and Validation Results in the Journal of the Society for Social Work and Research. Journal of the Society for Social Work and Research, 1(2), 99-103. https://doi.org/10.5243/jsswr.2010.8

Carden, S. W., Holtzman, N. S., \& Strube, M. J. (2017). CAHOST: An Excel Workbook for Facilitating the Johnson-Neyman Technique for Two-Way Interactions in Multiple Regression. Frontiers in Psychology, 8. https://doi.org/10.3389/fpsyg.2017.01293

Casteleyn, J. (2019). Improving public speaking in secondary education-Exploring the potential of an improvisation training. L1 Educational Studies in Language and Literature, Special Issue Assessing Oracy (Assessing Oracy). https://doi.org/10.17239/L1ESLL-2019.19.03.04

Connor, K. M., Kobak, K. A., Churchill, L. E., Katzelnick, D., \& Davidson, J. R. T. (2001). Mini-SPIN: A brief screening assessment for generalized social anxiety disorder. Depression and Anxiety, 14(2), 137-140. https://doi.org/10.1002/da.1055

Coppens, H. (2002). Training Teachers' Behaviour. Research in Drama Education. The Journal of Applied Theatre and Performance, 7(2), 195-206. https://doi.org/10.1080/1356978022000007974

D’Alonzo, K. T. (2004). The Johnson-Neyman Procedure as an Alternative to ANCOVA. Western Journal of Nursing Research, 26(7), 804-812. https://doi.org/10.1177/0193945904266733

De Coninck, K., Walker, J., Dotger, B., \& Vanderlinde, R. (2020). Measuring student teachers' self-efficacy beliefs about family-teacher communication: Scale construction and validation. Studies in Educational Evaluation, 64, 100820. https://doi.org/10.1016/j.stueduc.2019.100820

DeBettignies, B. H., \& Goldstein, T. R. (2019). Improvisational theater classes improve self-concept. Psychology of Aesthetics, Creativity, and the Arts. https://doi.org/10.1037/aca0000260

Di Giunta, L., Eisenberg, N., Kupfer, A., Steca, P., Tramontano, C., \& Caprara, G. V. (2010). Assessing Perceived Empathic and Social Self-Efficacy Across Countries. European Journal of Psychological Assessment : Official Organ of the European Association of Psychological Assessment, 26(2), 7786. https://doi.org/10.1027/1015-5759/a000012

Dontsov, A., \& Perelygina, E. (2014). Interpersonal confidence as a factor in the prevention of disorganized interaction. Psychology in Russia: State of the Art, 7(1), Article 1. https://doi.org/10.11621/pir.2014.0105

Drinko, C. D. (2013a). Keith Johnstone: Spontaneity, Storytelling, Status, and Masks, Trance, Altered States. In Theatrical Improvisation, Consciousness, and Cognition. Palgrave Macmillan. https://doi.org/10.1057/9781137335296

Drinko, C. D. (2013b). The Improvising Mind: On Stage and in the Lab. In Theatrical Improvisation, Consciousness, and Cognition. Palgrave Macmillan US. https://doi.org/10.1057/9781137335296

Duchatelet, D., Spooren, P., Bursens, P., Gijbels, D., \& Donche, V. (2021). Explaining self-efficacy development in an authentic higher education learning context of role-play simulations. Studies in Educational Evaluation, 68, 100940. https://doi.org/10.1016/j.stueduc.2020.100940

Felsman, P., Gunawardena, S., \& Seifert, C. M. (2020). Improv experience promotes divergent thinking, uncertainty tolerance, and affective well-being. Thinking Skills and Creativity, 35, 100632. https://doi.org/10.1016/j.tsc.2020.100632

Felsman, P., Seifert, C. M., \& Himle, J. A. (2018). The use of improvisational theater training to reduce social anxiety in adolescents. The Arts in Psychotherapy, 63, 111-117. https://doi.org/10.1016/j.aip.2018.12.001 
Gao, L., Peranson, J., Nyhof-Young, J., Kapoor, E., \& Rezmovitz, J. (2018). The role of “improv" in health professional learning: A scoping review. Medical Teacher, $0(0)$, 1-8. https://doi.org/10.1080/0142159X.2018.1505033

Gerber, E. (2009). Using improvisation to enhance the effectiveness of brainstorming. Proceedings of the 27th International Conference on Human Factors in Computing Systems - CHI 09, 97. https://doi.org/10.1145/1518701.1518718

Gillian-Daniel, A. L., Benjamin L. Taylor, \& Gillian-Daniel, D. L. (2020). Using Improvisation to Increase Graduate Students' Communication Self-Efficacy. Change: The Magazine of Higher Learning, 52(4), 46-52. https://doi.org/10.1080/00091383.2020.1794262

Graue, M. E., Whyte, K. L., \& Karabon, A. E. (2015). The power of improvisational teaching. Teaching and Teacher Education, 48, 13-21. https://doi.org/10.1016/j.tate.2015.01.014

Gruenewald, T. L., Kemeny, M. E., Aziz, N., \& Fahey, J. L. (2004). Acute Threat to the Social Self: Shame, Social Self-esteem, and Cortisol Activity. Psychosomatic Medicine, 66(6), 915-924. https://doi.org/10.1097/01.psy.0000143639.61693.ef

Hainselin, M., Aubry, A., \& Bourdin, B. (2018). Improving Teenagers' Divergent Thinking With Improvisational Theater. Frontiers in Psychology, 9. https://doi.org/10.3389/fpsyg.2018.01759

Hoffmann-Longtin, K., Rossing, J. P., \& Weinstein, E. (2018). Twelve tips for using applied improvisation in medical education. Medical Teacher, 40(4), 351-356. https://doi.org/10.1080/0142159X.2017.1387239

Ji, X. (2016). A Primer on the Johnson-Neyman Technique: An Alternative Procedure to ANCOVA. General Linear Model Journal, 42(1), 25-31.

Johnson, P. O., \& Neyman, J. (1936). Tests of certain linear hypotheses and their application to some educational problems. Statistical Research Memoirs, 1, 57-93.

Johnson, T. R. (2016). Violation of the homogeneity of regression slopes assumption in ANCOVA for twogroup pre-post designs: Tutorial on a modified Johnson-Neyman procedure. The Quantitative Methods for Psychology, 12(3), 253-263. https://doi.org/10.20982/tqmp.12.3.p253

Johnstone, K. (1985). Impro. Improvisation and the Theatre. Faber.

Johnstone, K. (1999). Impro for Storytellers: Theatresports and the Art of Making Things Happen (Main edition). Faber \& Faber.

Kirsten, B., \& du Preez, R. (2010). Improvisational theatre as team development intervention for climate for work group innovation: Original research. SA Journal of Industrial Psychology, 36(1), 1-9. https://doi.org/10.4102/sajip.v36i1.862

Lehtonen, A., Kaasinen, M., Karjalainen-Väkevä, M., \& Toivanen, T. (2016). Promoting Creativity in Teaching Drama. Procedia - Social and Behavioral Sciences, 217, 558-566. https://doi.org/10.1016/j.sbspro.2016.02.046

Lobman, C. (2005). "Yes And": The Uses of Improvisation for Early Childhood Professional Development. Journal of Early Childhood Teacher Education, 26(3), 305-319. https://doi.org/10.1080/10901020500371353

Lobman, C. (2006). Improvisation: An analytic tool for examining teacher-child interactions in the early childhood classroom. Early Childhood Research Quarterly, 21(4), 455-470. https://doi.org/10.1016/j.ecresq.2006.09.004

Lobman, C. (2014). "I Feel Nervous. . Very Nervous" Addressing Test Anxiety in Inner City Schools Through Play and Performance. Urban Education, 49(3), 329-359. https://doi.org/10.1177/0042085913478621

Mason, M., Magee, J. C., \& Fiske, S. T. (2014). Neural Substrates of Social Status Inference: Roles of Medial Prefrontal Cortex and Superior Temporal Sulcus. Journal of Cognitive Neuroscience, 26(5), 1131-1140. https://doi.org/10.1162/jocn_a_00553

Mourey, J. A. (2020). Improv Comedy and Modern Marketing Education: Exploring Consequences for Divergent Thinking, Self-Efficacy, and Collaboration. Journal of Marketing Education, 42(2), 134148. https://doi.org/10.1177/0273475318822087

Novák, J. (2017). Improvisaatiolla rohkeutta esiintymiseen? Opettajaksi opiskelevien kokemuksia improvisaatiokurssilta [Courage to perform through improvisation? Student teachers' experiences from an improvisation course. Master's thesis, University of Turku]. 
https://www.utupub.fi/bitstream/handle/10024/145803/gradu2017Novak.pdf?sequence=1\&isAllo wed $=\mathrm{y}$

Novák, J. (2020). Interpersonal Confidence Questionnaire (ICQ) Novák 2017. PsyArXiv. https://doi.org/10.31234/osf.io/jybzr

Pereira Christopoulos, T., Wilner, A., \& Trindade Bestetti, M. L. (2016). Experimental learning enhancing improvisation skills. The Learning Organization, 23(6), 415-428. https://doi.org/10.1108/TLO-042015-0027

Potthoff, R. F. (1964). On the Johnson-Neyman technique and some extensions thereof. Psychometrika, 29(3), 241-256. https://doi.org/10.1007/BF02289721

Preacher, K. J., Curran, P. J., \& Bauer, D. J. (2006). Computational Tools for Probing Interactions in Multiple Linear Regression, Multilevel Modeling, and Latent Curve Analysis. Journal of Educational and Behavioral Statistics; Washington, 31(4), 437-448. https://doi.org/10.3102/10769986031004437

Ranta, K., Kaltiala-Heino, R., Rantanen, P., \& Marttunen, M. (2012). The Mini-Social Phobia Inventory: Psychometric properties in an adolescent general population sample. Comprehensive Psychiatry, 53(5), 630-637. https://doi.org/10.1016/j.comppsych.2011.07.007

Ratten, V., \& Hodge, J. (2016). So much theory, so little practice: A literature review of workplace improvisation training. Industrial and Commercial Training, 48(3), 149-155. https://doi.org/10.1108/ICT-08-2015-0053

Raykov, T. (1997). Estimation of Composite Reliability for Congeneric Measures. Applied Psychological Measurement, 21(2), 173-184. https://doi.org/10.1177/01466216970212006

Richaud, M. C., Lemos, V. N., Mesurado, B., \& Oros, L. (2017). Construct Validity and Reliability of a New Spanish Empathy Questionnaire for Children and Early Adolescents. Frontiers in Psychology, 8. https://doi.org/10.3389/fpsyg.2017.00979

Robins, R. W., Hendin, H. M., \& Trzesniewski, K. H. (2001). Measuring Global Self-Esteem: Construct Validation of a Single-Item Measure and the Rosenberg Self-Esteem Scale. Personality and Social Psychology Bulletin, 27(2), 151-161. https://doi.org/10.1177/0146167201272002

Romanelli, A., \& Tishby, O. (2019). 'Just what is there now, that is what there is'-The effects of theater improvisation training on clinical social workers' perceptions and interventions. Social Work Education, O(0), 1-18. https://doi.org/10.1080/02615479.2019.1566450

Romanelli, A., Tishby, O., \& Moran, G. S. (2017). "Coming home to myself”: A qualitative analysis of therapists' experience and interventions following training in theater improvisation skills. The Arts in Psychotherapy, 53, 12-22. https://doi.org/10.1016/j.aip.2017.01.005

Rosenberg, M. (1965). Society and the adolescent self-image. Princeton University Press. https://doi.org/10.1515/9781400876136

Rubin, R. B., \& Martin, M. M. (1994). Development of a measure of interpersonal communication competence. Communication Research Reports, 11(1), 33-44. https://doi.org/10.1080/08824099409359938

Sawyer, K. (2004). Creative Teaching: Collaborative Discussion as Disciplined Improvisation. Educational Researcher, 33(2), 12-20. https://doi.org/10.3102/0013189X033002012

Sawyer, K. (2006). Group creativity: Musical performance and collaboration. Psychology of Music, 34(2), 148-165. https://doi.org/10.1177/0305735606061850

Sawyer, K. (2011). Structure and Improvisation in Creative Teaching. Cambridge University Press. https://doi.org/10.1017/CBO9780511997105

Sawyer, K. (2012). Extending Sociocultural Theory to Group Creativity. Vocations and Learning, 5(1), 5975. https://doi.org/10.1007/s12186-011-9066-5

Schwenke, D., Dshemuchadse, M., Rasehorn, L., Klarhölter, D., \& Scherbaum, S. (2020). Improv to Improve: The Impact of Improvisational Theater on Creativity, Acceptance, and Psychological Well-Being. Journal of Creativity in Mental Health, $0(0)$, 1-18. https://doi.org/10.1080/15401383.2020.1754987

Seeley-Wait, E., Abbott, M. J., \& Rapee, R. M. (2009). Psychometric Properties of the Mini-Social Phobia Inventory. The Journal of Clinical Psychiatry, 11(5), 231-236. https://doi.org/10.4088/PCC.07m00576 
Seppänen, S., Tiippana, K., Jääskeläinen, I., Saari, O., \& Toivanen, T. (2019). Theater Improvisation Promoting Interpersonal Confidence of Student Teachers: A Controlled Intervention Study. The European Journal of Social \& Behavioural Sciences, 24(1), 2770-2788. https://doi.org/10.15405/ejsbs.244

Seppänen, S., Toivanen, T., Makkonen, T., Jääskeläinen, I. P., Anttonen, M., \& Tiippana, K. (2020). Effects of Improvisation Training on Student Teachers' Behavioral, Neuroendocrine, and Psychophysiological Responses during the Trier Social Stress Test. Adaptive Human Behavior and Physiology, 6(3), 356-380. https://doi.org/10.1007/s40750-020-00145-1

Smith, H. M., \& Betz, N. E. (2000). Development and Validation of a Scale of Perceived Social SelfEfficacy. Journal of Career Assessment, 8(3), 283-301. https://doi.org/10.1177/106907270000800306

Spolin, V. (1999). Improvisation for the Theatre (Third Edition). Northwestern University Press.

Toivanen, T., Komulainen, K., \& Ruismäki, H. (2011). Drama education and improvisation as a resource of teacher student's creativity. Procedia - Social and Behavioral Sciences, 12, 60-69. https://doi.org/10.1016/j.sbspro.2011.02.010

Trotter, M. J., Salmon, P. M., \& Lenné, M. G. (2013). Improvisation: Theory, measures and known influencing factors. Theoretical Issues in Ergonomics Science, 14(5), 475-498. https://doi.org/10.1080/1463922X.2012.656153

Tunca, B. (2016). Using the Johnson-Neyman Procedure to Detect Item Bias in Personality Tests: A Proposed New Method and Practical Guidelines for Data Analysis. In U. Kumar (Ed.), The Wiley Handbook of Personality Assessment (pp. 346-360). John Wiley \& Sons, Ltd. https://doi.org/10.1002/9781119173489.ch25

Vera, D., \& Crossan, M. (2004). Theatrical Improvisation: Lessons for Organizations. Organization Studies, 25(5), 727-749. https://doi.org/10.1177/0170840604042412

Vera, D., \& Crossan, M. (2005). Improvisation and Innovative Performance in Teams. Organization Science, 16(3), 203-224. https://doi.org/10.1287/orsc.1050.0126

West, S., Hoff, E., \& Carlsson, I. (2017). Enhancing team creativity with playful improvisation theater: A controlled intervention field study. International Journal of Play, 6(3), 283-293. https://doi.org/10.1080/21594937.2017.1383000

Wright, P. R. (2006). Drama Education and Development of Self: Myth or Reality? Social Psychology of Education, 9(1), 43-65. https://doi.org/10.1007/s11218-005-4791-y

Zondag, A., Larsen, A. B., Guldal, T. M., \& Tillaar, R. van den. (2020). The influence of improvisation activities on speaking confidence of EFL student teachers. Nordisk Tidsskrift for Utdanning Og Praksis, 14(2), 82-102. https://doi.org/10.23865/up.v14.1879 


\section{Appendix A1. Interpersonal Confidence Questionnaire (ICQ)}

What do you think about these statements?

$0=$ strongly disagree, $1=$ disagree, $2=$ somewhat disagree, $3=$ somewhat agree, $4=$ agree, $5=$ strongly agree

1. I do not mind what other people think of me.

2. I prefer to work within a team.

3. When I am delivering a presentation, I focus primarily on keeping myself together.*

4. During a presentation, it disturbs me if my cheeks blush or my hands shake.*

5. I am afraid of sudden changes to my plans.*

6. I can easily concentrate on the task at hand.

7. I find it difficult to receive criticism.*

8. I give other people positive feedback.

9. If I have made a mistake, I take it with a sense of humor.

10. Usually I do not listen to what other people talk about.*

11. I find it easier to work alone than with someone.*

12. I am open to change.

13. I easily take things personally.*

14. I usually want things to be done in the most familiar way.*

15. I find it difficult to focus on being present in the here and now.*

16. I am a good listener.

17. I am anxious about saying something wrong.*

18. I am afraid of making mistakes when I perform.*

*Scale to be reversed. 


\section{Appendix A2. Interpersonal Confidence Questionnaire in Finnish}

\section{Mitä ajattelet väittämistä?}

$0=$ täysin eri mieltä, 1 = eri mieltä, $2=$ melko eri mieltä, $3=$ melko samaa mieltä, $4=$ samaa mieltä, $5=$ täysin samaa mieltä

1. En välitä siitä, mitä muut minusta ajattelevat.

2. Teen mieluiten töitä tiimissä.

3. Kun pidän esitystä, keskityn ensisijaisesti pitämään itseni koossa.*

4. Esiintyessäni minua häiritsee, jos punastun tai käteni tärisevät.*

5. Pelkään äkkinäisiä muutoksia suunnitelmissani.*

6. Minun on helppo keskittyä käsillä olevaan tehtävään.

7. Minun on vaikea ottaa vastaan kritiikkiä.*

8. Annan muille positiivista palautetta.

9. Otan huumorilla vastaan mokailuni.

10. En yleensä jaksa kuunnella mitä muut ihmiset puhuvat.*

11. Minusta on helpompi tehdä töitä yksin kuin jonkun kanssa.*

12. Suhtaudun avoimesti muutoksiin.

13. Otan helposti asiat henkilökohtaisesti.*

14. Haluan, että asiat tehdään useimmiten tutulla tavalla.*

15. Minun on vaikea keskittyä olemaan läsnä tässä ja nyt.*

16. Olen hyvä kuuntelija.

17. Jännitän, että sanon jotain väärin.*

18. Pelkään mokaavani esiintyessäni.*

*Asteikko käännettävä. 


\section{Appendix B}

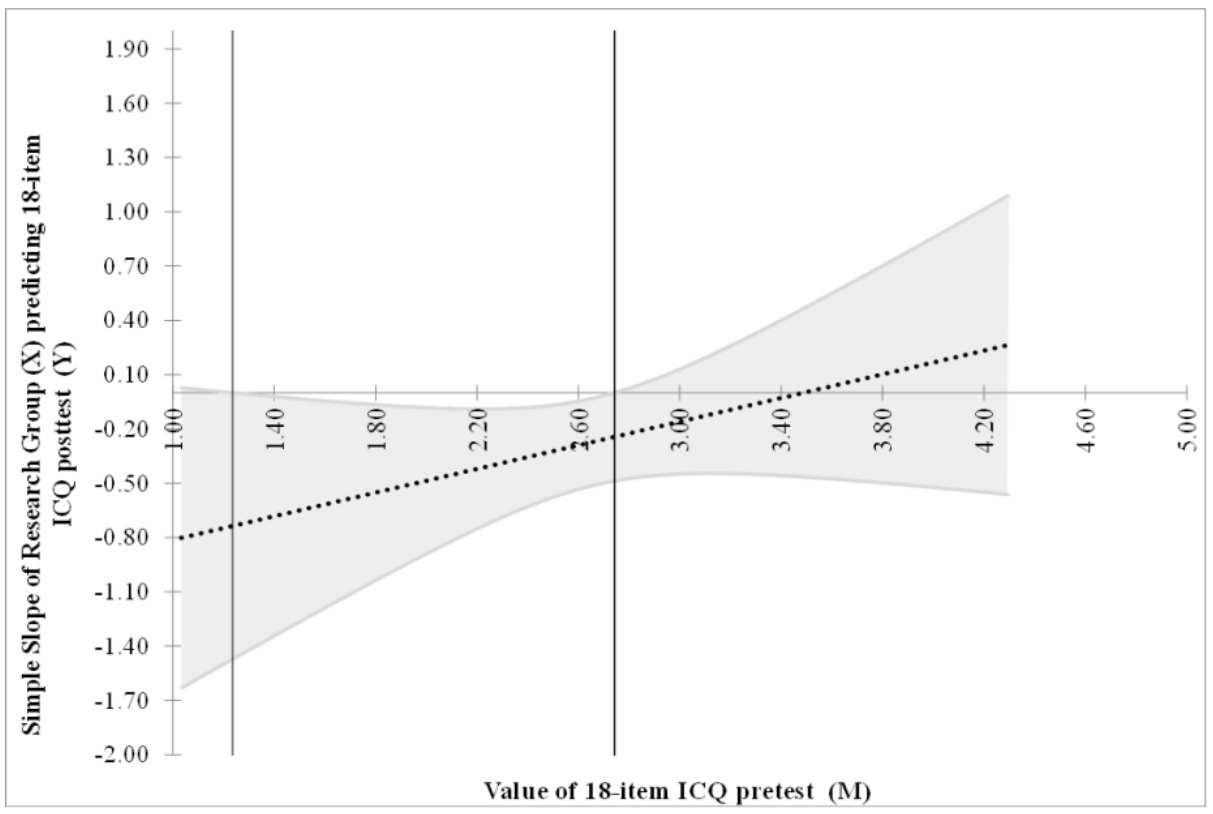

Figure B1a

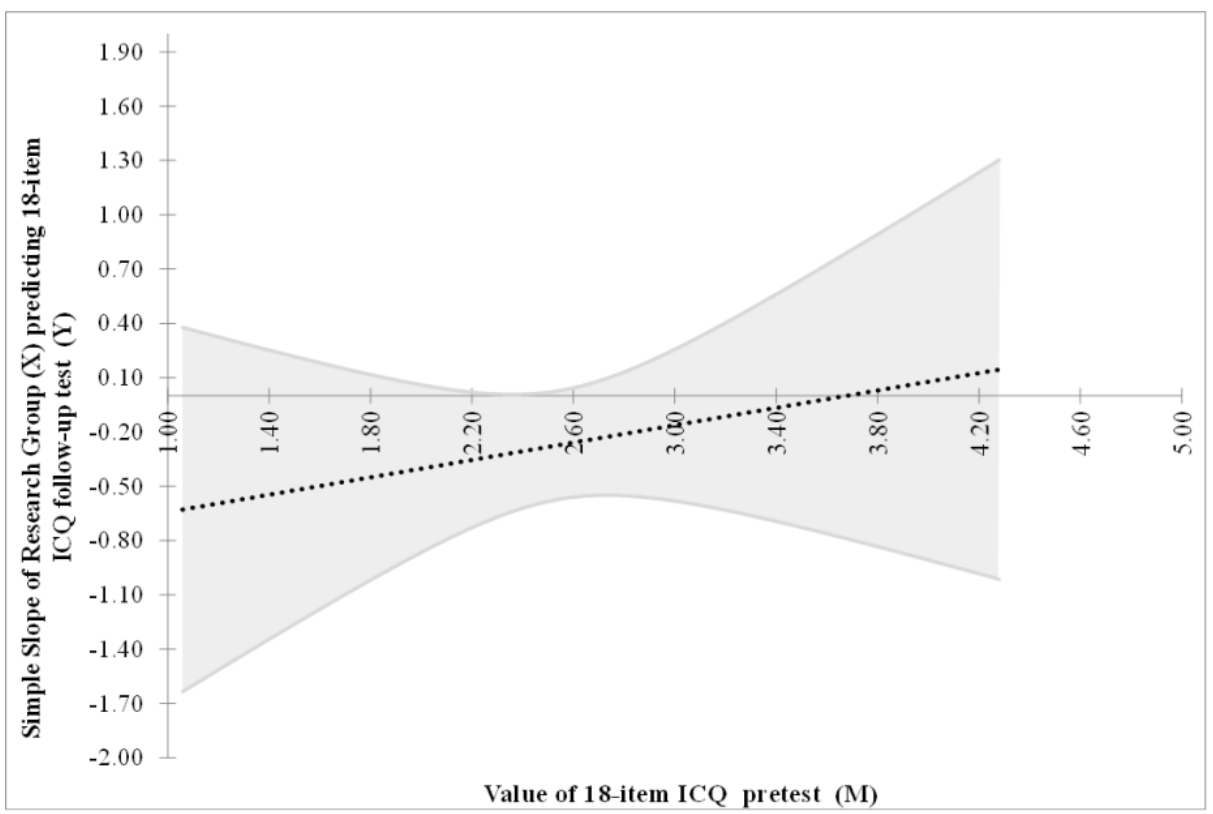

Figure B1b

Figure B1. Johnson-Neyman plot of the 18-item Interpersonal Confidence Questionnaire (ICQ).

The horizontal axis represents the pretest values of the 18-item Interpersonal Confidence Questionnaire (ICQ) and the dotted line represents the regression line for the research group predicting a) the posttest and b) follow-up test values for interpersonal confidence. The shaded area indicates the $95 \%$ confidence intervals (CIs). a) Posttest: the CI slope crosses over the significance barrier at 1.23 and 2.74, indicating a significant between-group difference when

the pretest value falls between 1.23-2.74. b) Follow-up test (one year following the intervention): no region of significance, indicating no between-group difference 


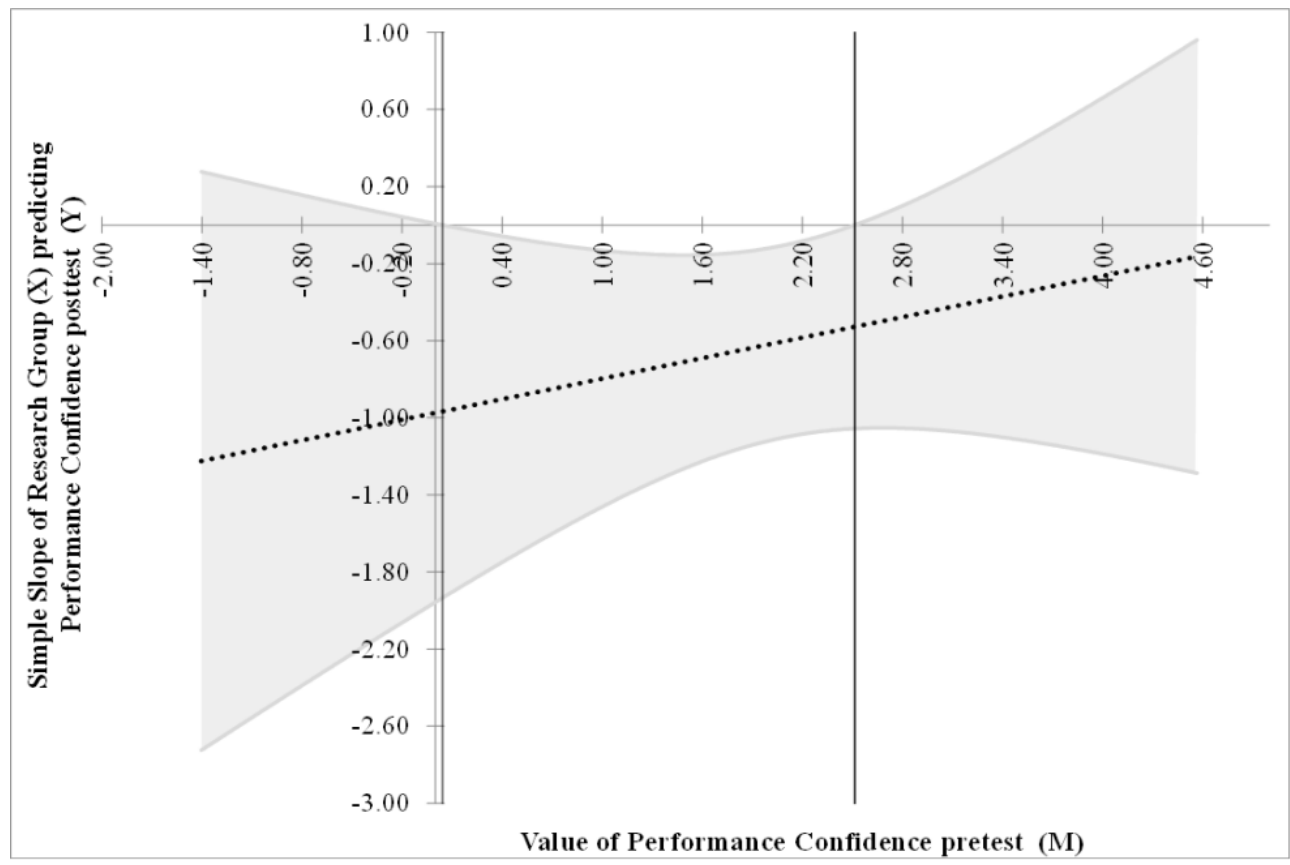

Figure B2a

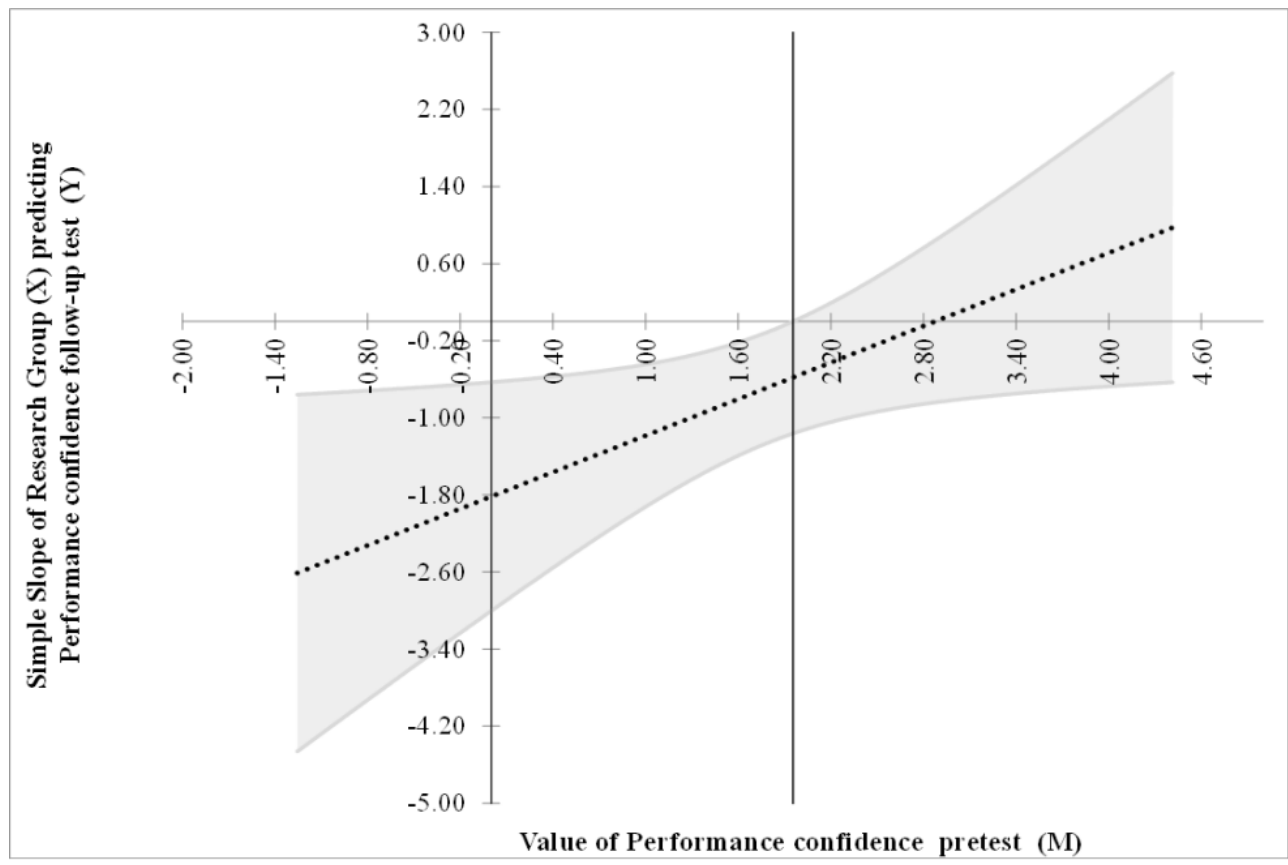

Figure B2b

Figure B2. Johnson-Neyman plot of the performance confidence factor.

The horizontal axis represents the pretest values for performance confidence and the dotted line represents the regression line of the research group predicting a) the posttest and b) follow-up test values for performance confidence. The shaded area indicates the 95\% confidence intervals (CI). a) Posttest: the CI slope crosses over the significance barrier at 0.04 and 2.51, indicating that the difference between research groups is significant when the pretest value falls between 0.04-2.51. b) Follow-up test (one year following the intervention): the CI slope crosses over the significance barrier at 1.96, indicating that the difference between research groups is significant when the pretest value is less than 1.96 